\title{
Monitoring Results of the Eagle Owl Population in the Strip-shaped Pine Forests in the Altail Kray, Russia
}

\section{РЕЗУЛЬТАТЫ МОНИТОРИНГА ПОПУЛЯЦИИ ФИЛИНА В ЛЕНТОЧНЫХ БОРАХ АЛТАЙСКОГО КРАЯ, РОССИЯ}

\author{
Karyakin I.V. (Center of Field Studies, N. Novgorod, Russia) \\ Карякин И.В. (Центр полевых исследований, Н.Новгород, Россия)
}

\section{Контакт: \\ Игорь Карякин \\ Центр полевых \\ иссиедований \\ 603109, Россия, \\ Нижний Новгород, \\ ул. Нижегородская, \\ 3-29 \\ тел.: +7831433 3847 \\ ikar_research@mail.ru}

\section{Contact:}

Igor Karyakin

Center of Field Studies

Nizhegorodskaya str.,

3-29

Nizhniy Novgorod,

Russia, 603000

tel.: +7831433 3847

ikar_research@mail.ru

\section{Резюме}

В статье слелана переоценка численности срилина (Bubo bubo) в Алтайских борах по результатам мониторинга 2013-2014 гг. В настоящее время в Алтайском крае известно 146 занятых гнездовых участков филинов, в том числе в алтайских борах - 90 гнездовых участков $(61,6 \%$ от общего числа занятых гнездовых участков в А^тайском крае). Сокрашение численности филина за последние 12 лет составило 46 \%, при этом наиболее масштабные потери популяции произошли в период после 2007 г. в связи с активизацией рубок леса в ленточных борах. Современная численность фрилина на гнездовании в равнинной части левобережья Оби в Алтайском крае в настоящее время может быть оценена в 233-253, в среднем 240 пар. Исследованиями показано, что на фоне сокрашения численности срилина происходит его уход с опушек вглубь боров, Аля гнездования филин

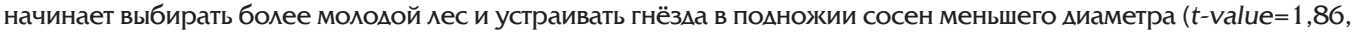
$d f=35, p=0,07)$. Успех размножения силина сократился с 65 ло 40,6 \%, а среднее число птенцов в выводках выросло с 1,87 до 3,15 птенцов на успешное гнезАо. По результатам анализа сракторов, влияющих на срилина, в статье слелан негативный прогноз динамики численности этого вида.

Киючевые слова: пернатые хишники, совы, филин, Вubo bubo, гнездовой участок, Алтайский край, ленточные боры.

Поступияа в реАакцию: 22.11.2014 г. Принята к публикации: 28.12.2014 г.

\section{Abstract}

Based on author's research in 2013-2014 the paper contains information on distribution, numbers and breeding biology of the Eagle Owl (Bubo bubo) in the strip-shaped pine forests in the Altai Kray. A total of 146 breeding territories of the Eagle Owl (61.6\% of the territories already known in the strip-shaped pine forests) located in the Altai Kray. Over the past 12 years the population of Eagle Owl declined by $46 \%$. With the most considerable population lost happened after 2007 caused by the intensification of deforestation in the strip-shape pine forests. Considering this fact, we can estimate the current population of the Eagle Owl inhabited the plains on the left bank of the Ob River in the Altai Region as 233-253 (mean 240) breeding pairs. Studies have shown that by a decline in the Eagle Owl population numbers being disturbed by loggers, some pairs of Eagle Owl could move from the forest margin to its depths. In the last few years Eagle Owls begun to occupied theirs nests under the smaller trees than before ( $t$-value $=1.86, d f=35, p=0.07$ ). Breeding success of the Eagle Owl decreased from 65 to $40.6 \%$, while the average number of chicks in broods increased from 1.87 to 3.15 nestlings to a successful nest. According to the analysis of negative factors influencing the Eagle Owl population - population dynamics of this species prognosed as negative.

Keywords: raptors, owls, Eagle Owl, Bubo bubo, breeding territory, Altai, pine forests.

Received: 22/11/2014. Accepted: 28/12/2014.

DOI: 10.19074/1814-8654-2014-29-77-92

\section{Введение}

Филин (Bubo bubo) широко распространённый в России виА, населяюший всю лесную и степную зоны страны, спораАично гнезАяшийся в полупустынной зоне, численность которого оценивается не мене чем в 40 тыс. гнездяшихся пар (Совообразные, 2014). Внесён в Красную книгу России - категория 2: широко распространённый, резко сокративший к концу XX в. численность на большей части ареала, местами исчезнувший (Воронецкий, 2001). Территория Алтайского края полностью входит в гнездовой ареал вила. Филин внесён в Красную книгу Алтайского края - категория 2: реАкий виА, сокрашаюший численность (Петров, 2006). К концу 2012 г. на территории Алтайского края было извест-

\section{Introduction}

Eagle Owl (Bubo bubo) is a wide-spread species in Russia, inhabits woodlands and steppe areas, and sparsely breeds in semidesert areas. The number of its population is not less then 40000 breeding pairs (Owls, 2014). Eagle owl is listed in the Red Book of endangered species of Russia as a species with reducing number (category II): in the $\mathrm{XX}$ century its population declined on the most part of its initial habitat, on some areas species became extinct (Voronetskiy, 2001). The breeding range of Eagle Owl covers the whole territory of the Altai Region of Russia. This species is listed in the Red Book of Altai Region under category II: rare species with reduced number (Petrov, 2006). 


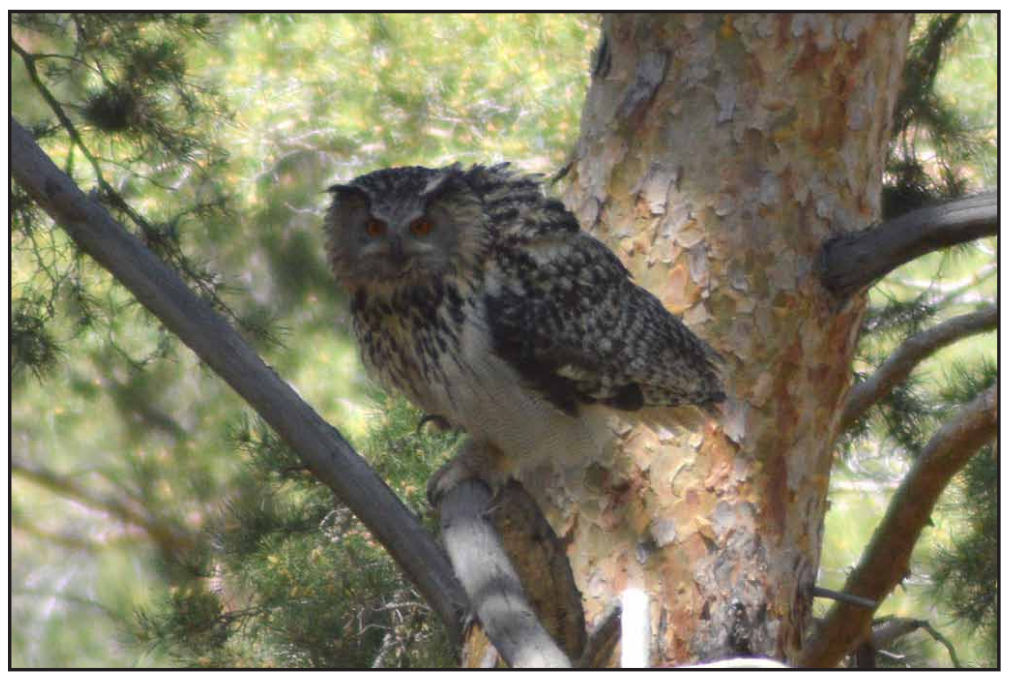

но, как минимум, 135 гнездовых участков филина (Карякин и мр., 2005; Смелянский, Томиленко, 2005; Смелянский и Ар., 2005; Карякин, 2007; Важков и Ар., 2010; Важов, 2012; Важков, Рыбаиьченко, 2013), абсо^ютное большинство которых выявлено в ленточных борах на Приобском плато (рис. 1). Численность вида в Алтайском крае по состоянию на 2007 г. оценивалась в 583-649, в среднем 615 гнездяшихся пар, из которых 431-469, в среднем 445 пар $(72,4 \%)$ гнездилось в равнинной части левобережья Оби, преимушественно в ленточных борах (Карякин, 2007).

В 2013-2014 гг. был проведён Аостаточно полный мониторинг гнездовых группировок филина в ленточных борах Аһтайского края, по результатам которого подготовлена данная статья.

\section{Методика}

Целенаправленное выявление гнездовых участков филина в Алтайском каре осу-

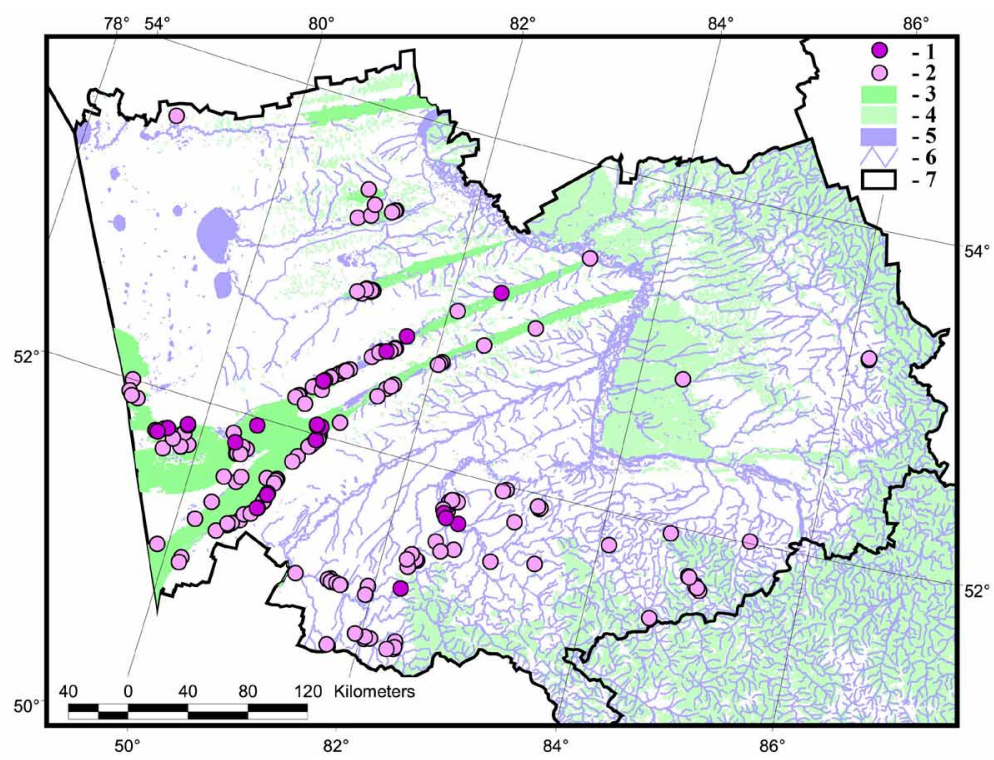

Филин (Bubo bubo). Фото И. Карякина.

Eagle Owl (Bubo bubo). Photo by I. Karyakin.

In 2007 the estimation number of Eagle Owl in Altai was 583-649 (mean 615) breeding pairs, with about 431-469 (mean 445) pairs (72.4\%) breed in the pine forest on the $\mathrm{Ob}$ Plateau (Karyakin, 2007).

At the and of 2012, non less then 134 breeding territories of the Eagle Owl were known in the Altai Region (Karyakin et al., 2005; Smelansky, Tomilenko, 2005; Smelansky et al., 2005; Karyakin, 2007; Vazhov, 2012, Vazhov, Rybalchenko, 2013). The vast majority of them located in the pine forest on the Ob Plateau.

In 2013-2014 our group conducted a thorough survey of the breeding populations of Eagle Owl in pine forests of Altai Region. This article summarize the results of the survey.

\section{Methods}

A goal-seeking searching for breeding sites of Eagle Owl in Altai Region is conducted by the organizations and researchers involved in the Eagle Owl Research and Protection Program (EORPP) of Russian Raptor Research and Conservation Network (RRRCN) since 2003 (Eagle Owl..., 2014).

In July 26-31 of 2013 surveying was conducted in the strip-shaped pine forests of Kasmalinskaya Lenta near lake Gorkoye and Kulundinskaya Lenta that is a part of Zavyalovskiy Wildlife Preserve, and in the eastern part of Kornilovskiy Wildlife Preserve. The length of the route lay through the plains of the left bank of River Ob within the borders of Altai Region covered by the expedition makes in total $1284 \mathrm{~km}$.

In May 3-21 of 2014 surveying was conducted in the separate plots of north-west border of the strip-shaped pine forest "Kas-

Рис. 1. Распространение срилина (Bubo bubo) в Аитайском крае. Условные обозначения: 1 - гнезАовые участки, выявленные в 2014 г., 2 - гнездовые участки, выявленные в 2003 - 2013 гг., 3 - ленточные боры Аитайского края, 4 - иные лесопокрытые территории А^тайского края, 5 - водоёмы, 6 - реки, 7 - амминистративные границы.

Fig. 1. Distribution of the Eagle Owl (Bubo bubo) in the Altai Kray. 1 - breeding territories revealed in 2014, 2 - breeding territories revealed in 2003 2013, 3 - strip-shaped pine forests of the Altai Kray, 4 - other woodlands of the Altai Kray, 5 - wetlands, 6 - small rivers, 7 -administrative borders. 
шествляется с 2003 г. организациями и исследователями, вовлеёнными в программу по изучению и охране филина Российской сети изучения и охраны пернатых хишников (Фикин..., 2014). Если в первые годы исследований основной упор был слелан на выяснение распределения фрилина (Карякин и мр., 2005; Карякин, 2007) и определение его численности, то в последнее время ведётся более или менее регулярный мониторинг отАельных гнезАовых группировок фрилина в Аитайском крае (Важов и мр., 2010; Важов, Рыбаиьченко, 2013).

В 2013 г. с 26 по 31 июля Аовольно быстро осмотрены участки Касмаминской боровой ленты в районе оз. Горькое, оконечность Кулундинской ленты (Завьяловский заказник) и восточная часть Корниловского заказника, маршрут экспедиции через равнинные районы левобережья Оби в пределах Аитайского края составил 1284 км. В 2014 г. с 3 по 21 мая Аостаточно хорошо были обследованы отдельные участки северо-запанного края Касмалинской менты, район Усть-Волчихи и Маминовых озёр, юго-восточный край Барнаульской ленты, в том числе Егорьевский заказник, маршрут экспедиции через равнинные районы левобережья Оби в прелелах Алтайского края составил 2160 км (рис. 2). На этих территория были осмотрены все гнездовые участки филина, выявленные в 2003-2004 гг. и проведён повторный учёт филина на 11 площацках, на которых базировамись оценки численности популяции филина в борах Аитайского края (Карякин, 2007). Также мы посетили практически все гнездовые участки фрилина, выявленные ранее С.В. Важовым, Р.Ф. Бахтиным и А.В. Рыбаиьченко, инсормация о которых опубликована

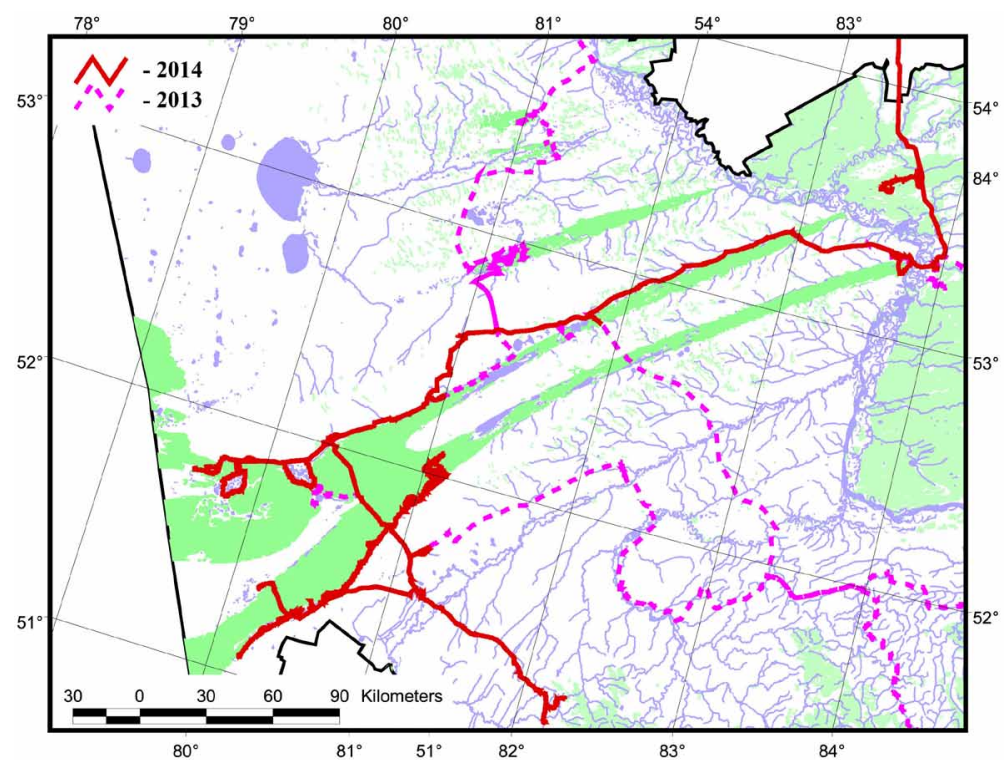

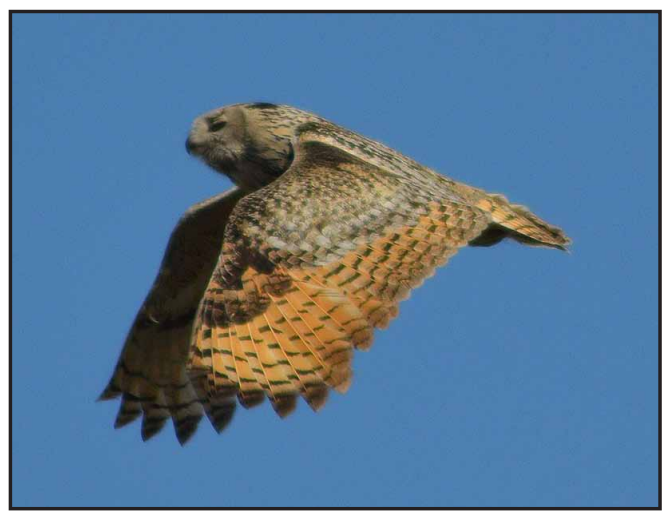

Филин. Фото И. Карякина.

Eagle Owl. Photo by I. Karyakin.

malinskaya Lenta", in the surroundings of Ust-Volchikha and Malinovoye Ozero villages, and in south-eastern border of the stripshaped pine forest "Barnaulskaya Lenta" including Yegoryevskiy Wildlife Preserve. The length of the route within the borders of Altai Region covered by the expedition makes $2160 \mathrm{~km}$ (fig. 2). On the sites listed above, we checked every breeding site of Eagle Owl revealed previously in 20032004 and conducted recount of the individual breeding sites on 11 sample plots that were formerly used in estimations of the population number of Eagle Owl in Altai Kray (Karyakin, 2007). We also visited the majority of the breeding sites of the Eagle Owls revealed by S.V. Vazhov, R.F. Bakhtin and D.V. Rybalchenko, which locations were published either in ornithological journals (Vazhov, Rybalchenko, 2013) or in Web-GIS "Faunistica" ("Raptors of the World" Section) of RRRCN (Vazhov, 2014a) or in the Red Book of the Altai Kray (Vazhov, 2014b).

The calculations of population number was conducted on the same 11 sample plots that were used in 2005 and 2007 (Karyakin et al., 2005; Karyain, 2007). The total area of the plots was $449.5 \mathrm{~km}^{2}$, area with a suitable forest habitat $-102.6 \mathrm{~km}^{2}$. The breeding density of Eagle Owl calculated on the sample plots was extrapolated on the whole area of the suitable forest habitats of the region. The extent of the suitable habitats in the plains on the left bank of River Ob is $970 \mathrm{~km}$ of forest margin bordered with wetlands plus $437.5 \mathrm{~km}$ of forest margin bordered with virgin steppe areas (Karyakin

Pис. 2. Маршруты экспедиций в 2013 и 2014 гг.

Fig. 2. Field tracks of 2013 and 2014. 
(Важов, Рыбаиьченко, 2013), либо внесена в Веб-ГИС "Фаунистика" Российской сети изучения и охраны пернатых хишников в разделах "Пернатые хищники Мира" (Важов, 2014а) и "Красная книга Алтайского края" (Важов, 2014b).

Работа по выявлению гнездовых участков филина проводилась как в дневное время, путём пешего обследования гнездопригодных биотопов, так и в ночное время, путём провоцирования вокамизации птиц голосом или с помощью аудиозаписей токуюших и беспокояшихся птиц. При пеших обследованиях гнездопригодных биотопов обрашали внимание на следы пребывания птиц - линные перья, погадки, останки жертв, "лунки", выкопанные птицами в подножиях деревьев. При обнаружении следов пребывания птиц, территория в радиусе $\Delta о 300$ м прочёсываяась группой из 2-3 человек в поисках гнезда.

В ходе мониторинга известных гнезАовых участков фрилина (с известными координатами старых гнёзд или присах) работа по поиску гнёзд велась анамогичным образом. В том случае, если на прежнем месте гнездования жилые или пустые с явными признаками размножения в этом году гнёзда обнаружены не были, провоАилось тщательное обследование территории в радиусе $\Delta$ о 300-500 м. Если при этом не удавалось обнаружить никаких следов пребывания фрилина, то гнездовой участок считался покинутым. Если следы пребывания срилина (линные перья и пух, остатки пиши, погаяки) были обнаружены в ралиусе 300-500 м от прежнего места гнездования, но активного гнезда не обнаружено, гнездовой участок считаися занятым, но без успешного размножения.

Птенцов в возрасте старше 25 Аней кольцевами стандартными аяюминиевыми

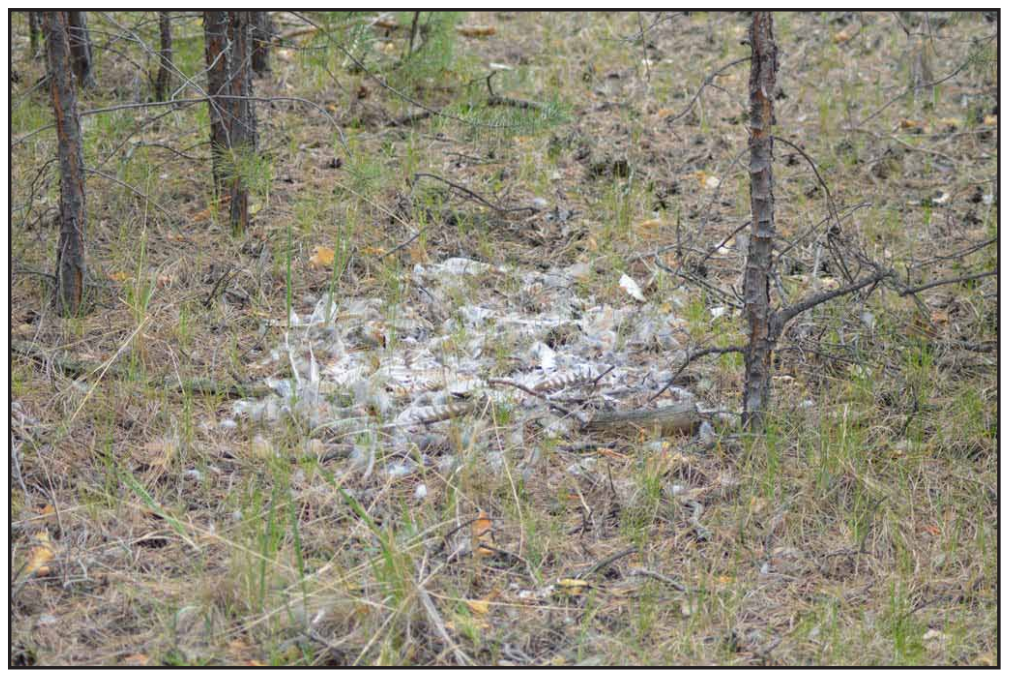

et al., 2005). The overall area of the suitable habitats in the strip-shaped pine forest is $835.1 \mathrm{~km}^{2}$ (Karyakin, 2007).

\section{Results \\ Population number and dynamics}

Until the end of 2014, 167 breeding territories of Eagle Owl were revealed in the Altai Kray. Among them 110 breeding territories in the strip-shaped pine forests covered the left bank of River Ob $(65.9 \%$ from the total number of the known breeding territories in the Altai Kray). In the period between 2008 and 2014 Eagle Owl disappeared on 21 breeding territories, including 20 in the strip-shaped pine forests. One hundred and fourth six breeding territories are still occupied, 90 of them located in the pine forest habitats $(61.6 \%$ from the number of occupied breeding territories in the Altai Kray) (fig. 3).

During expeditions of 2013-2014 we were able to visit 52 breeding territories of which 39 were situated on the sample plots. From the 39 breeding territories only 13 (33\%) permanently occupied by the Eagle Owl in the last 12 years. Over the past 12 years, 18 territories has disappeared and 8 has appeared on the sample plots (table 1). Thus, the population of Eagle Owl declined by $46 \%$. With the most considerable population lost happened after 2007 caused by the intensification of deforestation in the strip-shape pine forests.

The survey conducted by S.V. Vazhov and D.V. Rybalchenko (2013) in 2012 revealed that Eagle Owls abandoned 14 (50\%) out of 28 breeding territories that were checked. Two more breeding territories considered as probably abandoned because only old nests were found. Authors specified that the main reason that makes Eagle Owls to stop breeding and abandon theirs nests is deforestation that was conducted or is conducted directly at the nest locating sites. Surveys conducted in 2014 definitely confirms this trend.

The breeding density in the suitable habitats on the sample plots is $0.3 \pm 0.09$ pairs per $\mathrm{km}^{2}$. The linear characteristics of abundance of the species along the margin of forests bordered with wetlands is $2.27 \pm 0.12$ pairs per $10 \mathrm{~km}$ ( 1 pair per 4.4 $\mathrm{km}$ of the forest margin) and bordered with virgin steppe is $0.63 \pm 0.11$ pairs per $10 \mathrm{~km}$ (1 pair per $15.9 \mathrm{~km}$ of the forest margin). In comparison with the same characteristics obtained in 2003-2007: 0.54 \pm 0.17 pairs per $\mathrm{km}^{2}$, 1 pair per $2.6 \mathrm{~km}$ and 1 pair per 


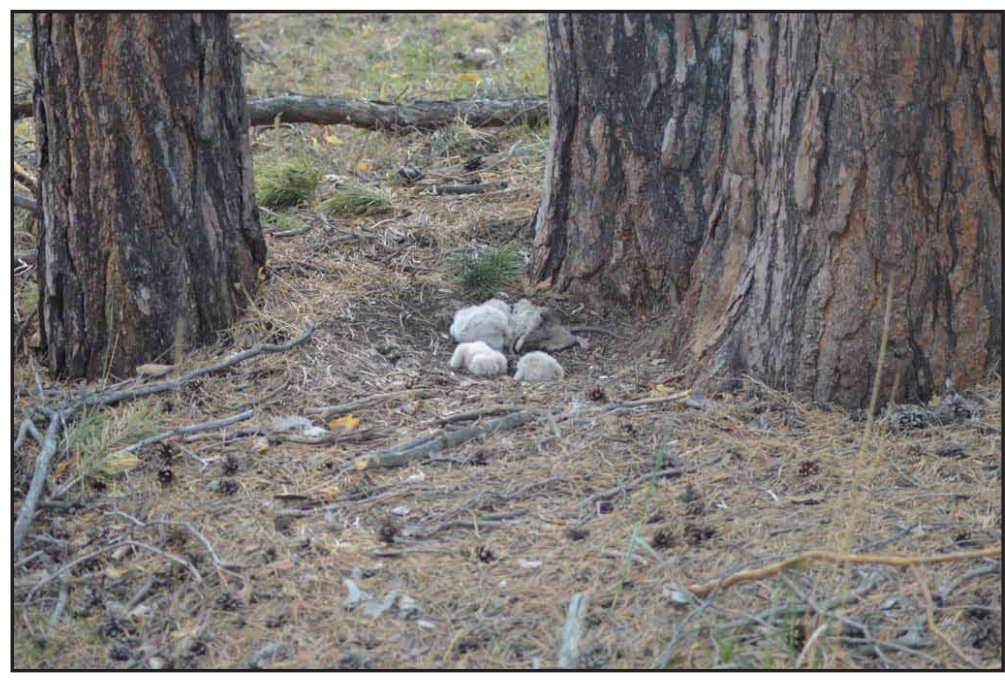

Типичное гнездо филина в бору.

Фото И. Карякина.

Typical nest of the Eagle Owl in the pine forest. Photo by I. Karyakin.

кольцами серии АА, которые были выданы московским Центром кольцевания птиц, а также цветными пластиковыми кольцами Российской сети изучения и охраны пернатых хишников.
Расчёт численности проведён по тем же 11 плошацкам, по которым оценка численности вила осушествлена в 2005 и 2007 гг. (Карякин и Ар., 2005; Карякин, 2007). Плошаць этих плошахок составила 449,5 км², плошадь гнездопригодного мля фрилина леса на них - 102,6 км². На гнездопригодные местообитания региона экстраполироваяись показатели плотности распределения гнездовых участков срилина, полученные на учётных площалках, в анамогичных местообитаниях. Методика подготовки векторной карты местообитаний фрилина мяя экстраполяции учётных Аанных, приведена в статье 2007 г. Протяжённость пригодных мяя гнездования филина местообитианий в равнинной части левобережья Оби определена в 970 км боровых опушек вАОль водно-болотных комплексов и 437,5 км боровых опушек вАоль нераспаханной степи (Карякин и Ар., 2005), а общая плошахь гнездопригодных местообитаний в менточных борах определена в 835,1 км² (Карякин, 2007).

\section{Результаты \\ Численность и её динамика}

К концу 2014 г. в Алтайском крае было выявлено 167 гнездовых участков фрилинов, в том числе 110 гнездовых участков в ленточных борах в левобережье Оби $(65,9 \%$ от обшего числа известных гнезАовых участков в Алтайском крае). За периол с 2008 по 2014 гг. фрилин прекратил размножение на 21 гнездовом участке, в том числе на 20 гнездовых участках в ленточных борах. Занятыми оставались 146
$7.95 \mathrm{~km}$ respectively (Karyakin et al., 2005; Karyakin, 2007), population number declining varies from $45 \%$ to $50 \%$. Decrease of the breeding density of pairs that prefer dry forest margins bordered with steppe is higher than those that choose periphery of swamps and lakes.

Analysis of satellite images showed systematically deforestation works over the whole area of strip-shaped pine forest (fig. $4)$. And it is the sole reason of the declining of the population number of Eagle Owl. Thus, parameters of population decline calculated for the sample plots could be extrapolate to the whole area of strip-shaped pine forest. Considering this fact, we can estimate the current population of the Eagle Owl inhabited the plains on the left bank of the Ob River in the Altai Kray as 233-253 (mean 240) breeding pairs. This means that the population that breeds in the flat part of the Altai Kray lost half of it number over the last 7 years.

\section{Alterations in habitat choice and dis- tribution}

It is clear that strip-shaped pine forest suffered strong alterations connected with massive deforestation over the past 5 years. Recently forest margins and forest on the banks of the lakes and bogs including ones that located in the protected areas were allotted for cutting that means that new breeding territories of Eagle Owls would be destroyed soon.

Being disturbed by loggers, some pairs of Eagle Owl could move from the forest margin to its depths. We found that 8 breeding pairs out of 32 (25\%) moved theirs nests $90-400 \mathrm{~m}$ in woods, so the spatial pattern of the breeding groups virtually left unchanged (with reduced number of breeding pairs in group and increased distances between the groups, the distance between closest neighbors in the group left unchanged). For instance, in 2003-2005 the distance between the closest neighbors varied from 0.99 to $8.70 \mathrm{~km}$ with the aver-

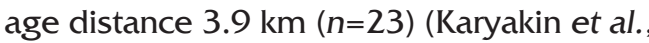
2005), and in 2014 same distance makes $0.71-9.72 \mathrm{~km}$ with the average distance $3.63 \pm 2.69 \mathrm{~km}(n=58)$ (fig. 5). In this calculations we do not consider the distances less or equal then $200 \mathrm{~m}$ between the neighboring nests as a distance between the different pairs as it is related to the fact of polygyny (Karyakin, Nikolenko, 2013).

In the forest Eagle Owl prefers thinned parts with aged trees, especially pine 


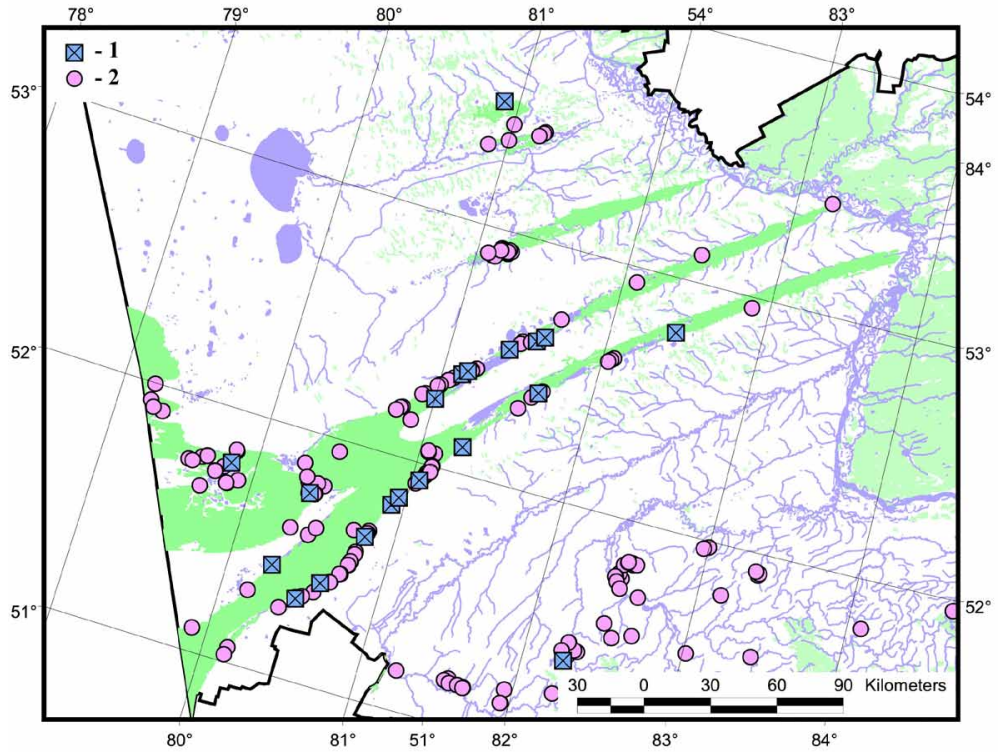

гнездовых участков, в том числе 90 гнездовых участков в аитайских борах (61,6 \% от обшего числа занятых гнездовых участков в Алтайском крае) (рис. 3).

В ходе исследований 2013-2014 гг. в ленточных борах Аитайского края удамось посетить 52 гнездовых участка, в том числе 39 на плошадках. В связи с тем, что на плошацках обследование территории осушествлялось более детаиьно, то здесь недоучёт птиц менее вероятен, чем на территориях за пределами мониторинговых плошадок, поэтому показатели занятости участков более объективны. Из 39 участков за последние 12 мет мишь на 13 (33 \%) пребывание фрилина носит регулярный характер. За это время на
Рис. 3. Гнездовые участки фрилина в Аитайском крае. Условные обозначения: 1 - исчезнувшие гнездовые участки, 2 - занятые гнездовые участки.

Fig. 3. Breeding territories of the Eagle Owl in the Altai Region. 1 - currently non-existing breeding territories (were occupied in the past), 2 - currently occupied breeding territories.

woods. But from year to year it became more difficult for Eagle Owl to find a good breeding site. During the logging forest loses its biggest trees, rejuvenate, and became suboptimal for the Eagle Owls. Since Eagle Owl is an early-breeding species, it starts incubating before the snow melts. In strip-shaped pine forests it makes nests solely on the ground placing them at the base of hugest pines where snow piles disappear earlier. Additionally, big trees help Eagle Owl to disguise better - the grown up nestlings sitting on the ground merge into the big trunks on the background, but stand out clearly against the thin trees.

With the lack of big trees in the forest, Eagle Owl has to breed in the less comfortable and less secure places making its nests under the small trees, which had to affect negatively reproductive success of the species.

We don't have enough data yet to calculate reliable correlations between the reproductive success and the diameter of the nesting trees, but it is clear that in the last few years Eagle Owls begun to occupied theirs nests under the smaller trees than be-

Табл. 1. Аинамика числа гнездовых участков филина (Bubo bubo) в ленточных борах по результатам 2014 г.

Table 1. Trends in the number of breeding territories of the Eagle Owl (Bubo bubo) in strip-shaped pine forests built on the results of population monitoring in 2014.

\begin{tabular}{|c|c|c|c|c|c|c|}
\hline & $\begin{array}{r}\text { Bсе } \\
\text { посешавшиеся } \\
\text { гнездовые } \\
\text { участки } \\
\text { All the sur- } \\
\text { veyed breeding } \\
\text { territories }\end{array}$ & $\begin{array}{r}\text { Доля от } \\
\text { обшего числа } \\
\text { участков (\%) } \\
\text { Share from } \\
\text { the surveyed } \\
\text { breeding ter- } \\
\text { ritories (\%) }\end{array}$ & $\begin{array}{r}\text { Аоля от числа } \\
\text { занятых } \\
\text { участков (\%) } \\
\text { Share from } \\
\text { the occupied } \\
\text { breeding ter- } \\
\text { ritories (\%) }\end{array}$ & $\begin{array}{r}\text { Гнездовые } \\
\text { участки на } \\
\text { плошамках } \\
\text { Breeding ter- } \\
\text { ritories on the } \\
\text { plots }\end{array}$ & $\begin{array}{r}\text { Доля от } \\
\text { общего числа } \\
\text { участков (\%) } \\
\text { Share from } \\
\text { the surveyed } \\
\text { breeding ter- } \\
\text { ritories (\%) }\end{array}$ & $\begin{array}{r}\text { Доля от } \\
\text { числа } \\
\text { занятых } \\
\text { участков (\%) } \\
\text { Share from } \\
\text { the occupied } \\
\text { breeding ter- } \\
\text { ritories }(\%)\end{array}$ \\
\hline Стабильные / Stable & 18 & 34.62 & & 13 & 33.33 & \\
\hline Исчезнувшие & & & & & & \\
\hline Disappeared & 20 & 38.46 & & 18 & 46.15 & \\
\hline Новые / New & 14 & 26.92 & & 8 & 20.51 & \\
\hline ПОСЕШАВШИЕСЯ & & & & & & \\
\hline SURVEYED & 52 & & & 39 & & \\
\hline Занятье & & & & & & \\
\hline Occupied & 32 & 61.54 & & 21 & 53.85 & \\
\hline $\begin{array}{l}\text { Успешные } \\
\text { Successful }\end{array}$ & 13 & 25.00 & 40.625 & 10 & 25.64 & 47.62 \\
\hline $\begin{array}{l}\text { Безуспешные } \\
\text { Unsuccessful }\end{array}$ & 19 & 36.54 & 59.375 & 11 & 28.21 & 52.38 \\
\hline
\end{tabular}


Уничтоженное рубками гнездо филина в Егорьевском заказнике. Фото И. Карякина.

A nest destroyed by loggers in the Preserve.

Photos by I. Karyakin. Yegoryevskiy Wildlife

плошацках исчезло 18 участков, а появилось 8 (табл. 1). Таким образом, сокрашение численности филина за последние 12 лет составило 46 \%, при этом наиболее масштабные потери популяции произошли в период после 2007 г. в связи с активизацией рубок леса в ленточных борах.

В 2004-2008 гг. ежегодно на плошалках проверяли около десятка гнездовых участков филина в год - баланс числа покинутых и появившихся участков сохранялся. Негативные тенденции стали очевидными в 2009 г., когАа по Аанным полевого обследования боровых опушек в Волчихинском, Мамонтовском, Ребрихинском и Завьяловском районах была выявлена потеря 20 \% участков, уничтоженных рубками.

Мониторинг, проведённый С.В. Важковым и А.В. Рыбаиьченко (2013) в 2012 г. показаи, что фиилинами покинуто 14 (50 \%) гнезАовых участков из 28 проверенных и ешё

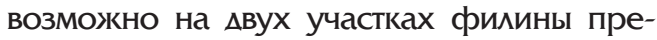
кратили размножение (зАесь были найдены только старые гнёзда). В основе причин прекрашения размножения срилина авторы указывают рубки леса, провелённые и/или

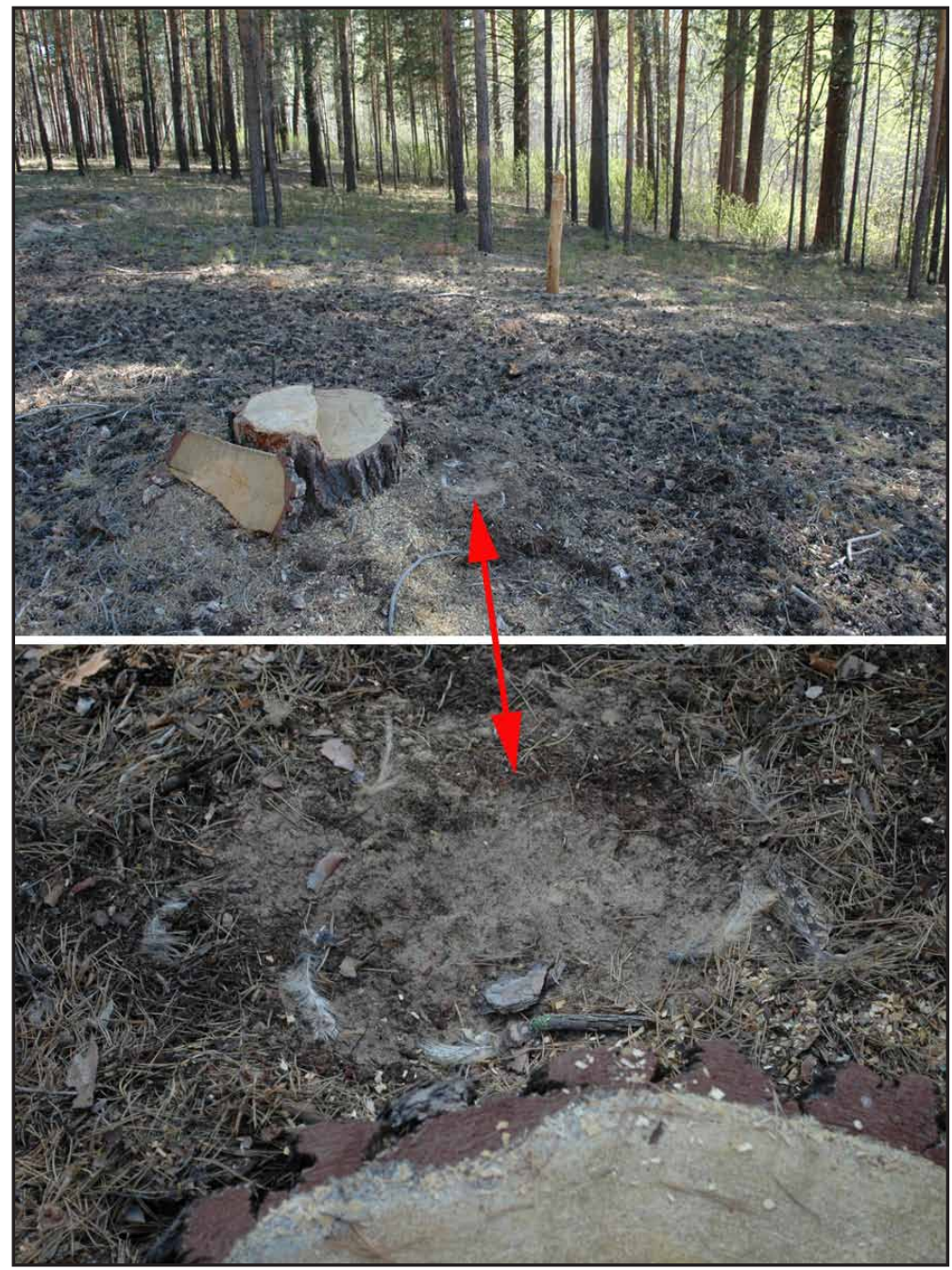

fore $(t$-value $=1.86, d f=35, p=0.07)$. Before 2009 diameter of the trunk varies from 30 to $100 \mathrm{~cm}$ with the mean value $55.5 \pm 18.2$ $\mathrm{cm}(n=20)$. Today this size varies from 10 to $90 \mathrm{~cm}$ with the mean value $43.53 \pm 20.9 \mathrm{~cm}$ $(n=17)$ (fig. 6).

\section{Breeding success}

The logging that is conducted in the breeding period (from March to July) also has a strong negative effect on the reproductive success of the Eagle Owl. In 2014, only 13 pairs out of $32(40.6 \%)$ were able to raise offspring and 19 were unsuccessful. Seventeen pairs our of 19 were disturbed by logging in the close vicinity or even by logging directly at the nest site when the tree that was already used by owls was felled. We can state that in the past 11 years more than half Eagle Owl pairs became unsuccessful in breeding, which is caused by deforestation. The data from 2003 shown that successful breeding was observed at $65 \%$ of breeding territories $(n=54)$ (Karyakin et al., 2005), but in 2012 this value dropped to $41.7 \%$ (Vazhov, Rybalchenko, 2013).

In Altai Region, the number of nestlings in the brood in 2003-2005 was 1-3 with the average value $1.87 \pm 0.69(n=23)$ owlets per nest (unsuccessful pairs are not count) (Karyakin et al., 2005). In 2012 we found two broods with three nestlings, two broods with two nestlings and one nest with one nestling that in average gives us $2.20 \pm 0.84(n=5)$ owlets per nest (Vazhov, Rybalchenko, 2013). In 2014 brood size was $2-4$ nestlings and the average number gives $3.15 \pm 0.55$ owlets per nest (fig. 7). However, in 2014 we observed a significant phenological shift so the most pairs of the Eagle Owl started to breed 2-3 weeks later than normally. Thus, in the most nests we found owlets in the first down plumage, but not in mezoptile, which means that we checked nests before the period of the highest mortality among nestlings. However, the trend for growing number of nestlings in a brood is taking place, but it happened on the background of the general declining of both breeding success and population number (fig. 8). Probably it is a population response to the reducing number.

\section{Treats}

In the Altai pine forests the main treats for the Eagle Owl are habitat lost due to deforestation and wildfires, but the first cause prevails. As it was shown before, logging 


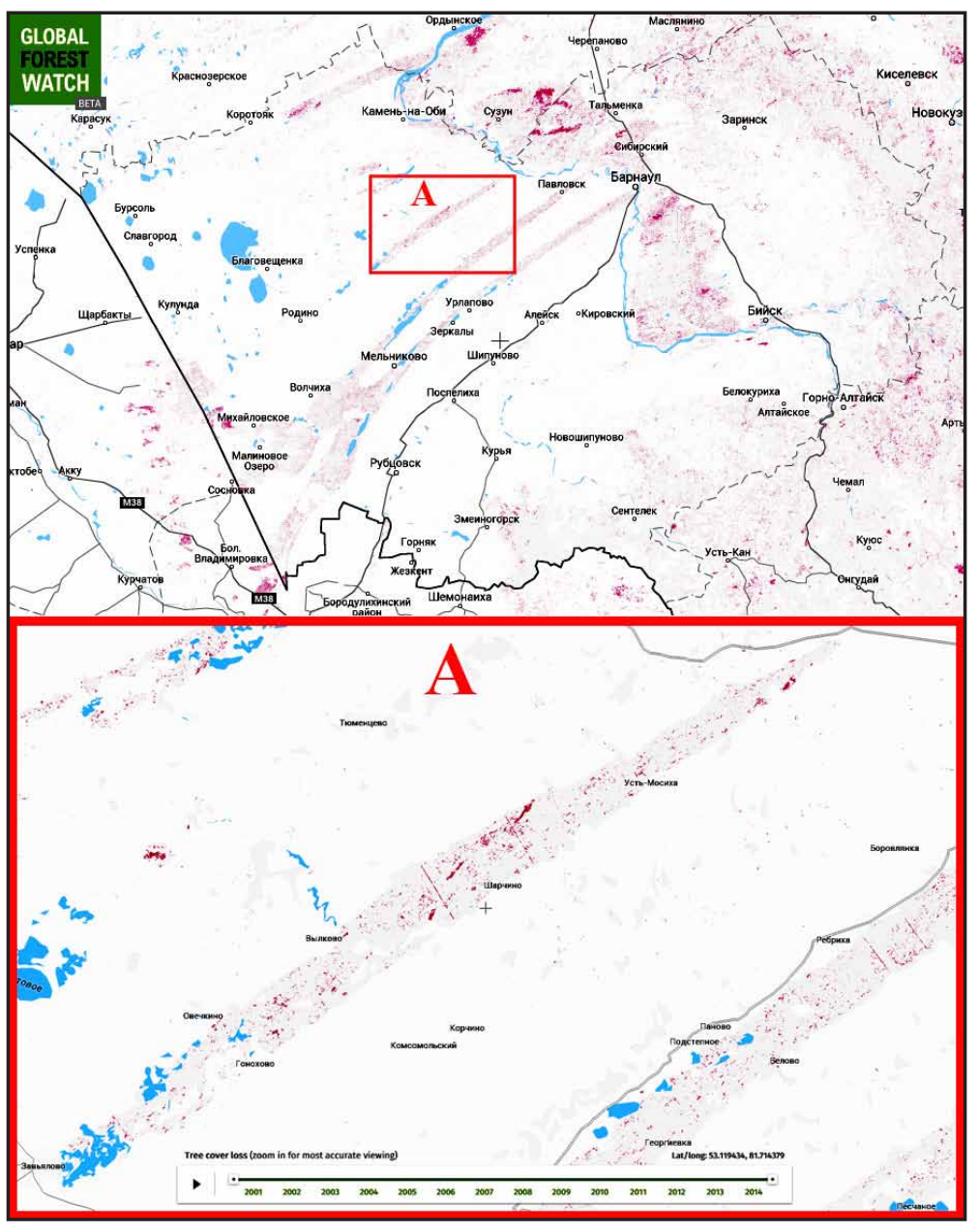

Рис. 4. Потери лесных плошацей в Аитайском крае по Аанным Аистанционного зондирования земии: разрешение 30 м., показаны киастеры, в которых потеря пиотности Аревостоя составляет более $30 \%$. Global Forest Watch, 2014.

Fig. 4. Forest habitat losses in the Altai Region according to satellite imagery data obtained from Global Forest Watch 2014. Clusters that lost more than $30 \%$ of forest are shown. Resolution: $30 \mathrm{~m}$. reduces the area of suitable breeding habitat so the most breeding pairs failed to rise offspring successfully. Low reproductive success causes the prevail of the mortality rate over the birth rate soon, which leads to population decline.

We know about four cases of Eagle Owl's death caused by electrocution on power lines with capacity of $6-10 \mathrm{kV}$. One case was revealed in the foothills of Altai mountains (Karyakin et al., 2009) and three in the plains of the left bank of Ob River. In the first case a young bird was killed by electrocution near the Gilev Log village in Romanovskiy district on September $21^{\text {st }}$ of 2012 (Karyakin, Nikolenko, 2013). In two other cases, carcasses of two adult birds were found on theirs breeding territories during the breeding period. Both birds died in 100-600 m from theirs nests.

The length of bird-hazardous power lines (6-10 kV power transmission lines strung on concrete poles with pin-type insulators) in the plains of the left bank of River $\mathrm{Ob}$ in the Altai Kray is about $1200 \mathrm{~km}$.

Considering the minimal rates of mortality of Eagle Owls from electrocution as $0.07-0.23$ ind. per $10 \mathrm{~km}$ (Karyakin et al., 2009) we can estimate the killing rate as 8-28 birds per year. It corresponds to $3.5 \%$ - $11.5 \%$ from the current population number. However, this approximation is rough since no detailed survey of power lines was conducted at the period when Eagle Owl is most vulnerable for this treat - at the end of breeding season when the owls families breakup and young birds begin to live separately (September-October).

We know very little about the influence of poaching on this species, because cases of illegal hunting became public in seldom occasions. We ascertained the shooting of Eagle Owls only on three breeding territories located in pine forests. In 2014 an adult bird with a wing trauma was delivered to the falcon nursery "Altai-Falcon" for rehabilitation. This bird was wounded at its breeding territory located near lake Kochenyovo in Yegoryevskiy District of Altai Kray. The nesting tree of this bird was allotted for cutting and lately it was ravaged. We assumed that the killing of the adult bird from this territory was also premeditated. The estimated damage for the Eagle Owl population from poaching is non less then $5-10 \%$ of it number per year. But the real value could by considerably higher.

The mortality of Eagle Owls on the highways is minimal. We learned about 2 cases планомерно по всей их территории (рис 4). Сокрашение численности силина про- боров вАоль степи, выше, чем пар, гнезАившихся по периферии болот и озёр.

Анамиз космоснимков показывает, что нарушение рубками боров идёт Аостаточно 
исходит практически искиючительно по причине рубок. Следовательно, показатели сокрашения численности фрилина на плошацках, могут экстраполироваться на всю площаць менточных боров. Учитывая это, численность филина на гнездовании в равнинной части левобережья Оби в Алтайском крае в настояшее время может быть оценена в 233-253, в среднем 240 пар. Таким образом, гнездяшаяся в равнинной части края популяция фрилина за последние 7 лет потеряла фактически половину особей, участвовавших в размножении.

\section{Изменения в распределении и выбо- ре местообитаний}

Очевинно, что за последние 5 лет в результате массированных рубок ленточные боры претерпели серьёзные изменения. При этом в последнее время под рубку отводятся опушки боров и побережья воАоёмов, в том числе и на особо охраняемых природных территориях (ООПТ), что захватывает всё большие гнездовые участки филинов, вынужАая птиц постоянно перемешаться. Аия 8 пар филинов из 32 (25\%) Аоказан уход вглубь леса от опушек на 90-400 м, при этом пространственная структура гнездовых группировок остаётся фрактически прежней (численность гнездяшихся пар в группах уменьшается, Аистанции межАу группами увеличиваются, при сохранении Аистанций межАу ближайшими соседями). Если в 2003-2005 гг. Аистанции межАу ближайшими соседями варьироваки от 0,99 $а$ о 8,70 км, составляя в среднем $(n=23)$ 3,9 км (Карякин и мр., 2005), то в 2014 г. этот показатель стаи 0,71-9,72 км, в среднем ( $n=58)$ 3,63 $\pm 2,69$ км (рис. 5). При анаиизе дистанций мы не учитываем ing breeding pairs of the Eagle Owl. only. Carcasses of two birds knocked by cars were found on the roadside of asphalted roads skirted along forest margin in Mikhaylovskiy and Zavyalovskiy districts of Altai Region. Only $12 \%$ from the forestbreeding population of Eagle Owl are in the risk group, thus the damage from this treat couldn't be high.

Young birds are the most vulnerable part of the population for all kinds of treats from the nest ravaging to death from electrocution. In September, young birds leave theirs parents and begin to move away from theirs born places on dozens or even hundreds km. Visual observations showed that in autumn young Eagle Owls concentrate around farms close to the villages where they prey on rats, crow species (Corvidae) and Black Kites (Milvus migrans lineatus) that occur in such places in high abundance. However, in this habitats Eagle Owls are much more vulnerable to the treats caused by humans.

Ring recoveries (fig. 9) confirmed the wide spreading of young birds in autumn and the fact that they often died in the outskirts of settlements (Vazhov et al., 2014):

A - a young Eagle Owl that was tagged by the author near Seliverstovo village in Volchikhinskiy district of Altai Region ${ }^{13}$ on the $25^{\text {th }}$ of July of 2012 . The bird died from electrocution near the village Gilyov Log of Romanovskiy district on the $21^{\text {st }}$ of September of $2012^{14}$. Distance from the nest is 52 $\mathrm{km}$, azimuth 7 degree, life-span 59 days.

B - a young Eagle Owl that was tagged by S. Vazhov in Zmeinogorskiy district of Altai Region on the $30^{\text {rd }}$ of May of $2012^{15}$. The bird was found dead in the granary in the village Gagarino of Ulanskiy district of East-Kazakhstan Region of the Kazakhstan Republic on the 6th of January of $2013^{16}$. Distance from the nest is $118 \mathrm{~km}$, azimuth 183 degree, life-span 222 days.

C - a young Eagle Owl that was tagged by S. Vazhov in Chariishskaya Steppe of Altai Kray on the $28^{\text {th }}$ of May of $2014^{17}$. The bird was found dead in the bushes on the bank of the Shemonaikha River in the Kazakhstan Republic by A. Zhuravlyov on the $16^{\text {th }}$ of December of $2014^{18}$. Distance from the nest is $129 \mathrm{~km}$, azimuth 198.6 degree, life-span 203 days.

\section{Conclusion}

Eagle Owl is a typical species of Altai pine forests. However, recently its population loose nearly half of its mature individuals. And the main reason is habitat lost due to 
расстояние между Авумя жимыми гнёздами фрилина в 200 м как Аистанцию между соседями, относя этот факт к полигинии - см. Карякин, Николенко, 2013).

Уходя от рубок вглубь леса, филин старается выбирать разреженный лес со старыми деревьями, в котором он предпочитает гнездиться в борах, однако с каждым годом это ему становится всё труднее и труднее. В ходе выборочных рубок уничтожаются как раз наиболее крупные сосны, лес омолаживается и становится субоптимальным мия филина. Филин - рано гнездяшийся вид, на киалку он садится ешё при снежном покрове. В менточных борах он гнездится искюючительно на земле, устраивая гнёзда в основании крупных сосен. Связано это в первую очередь с тем, что вокруг комлей крупных сосен снег обтаивает раньше. К тому же крупные $л е-$ ревья позволяют фрилину лучше маскироваться - подросшие птенцы, лежашие на земле, фрактически сливаются с крупными

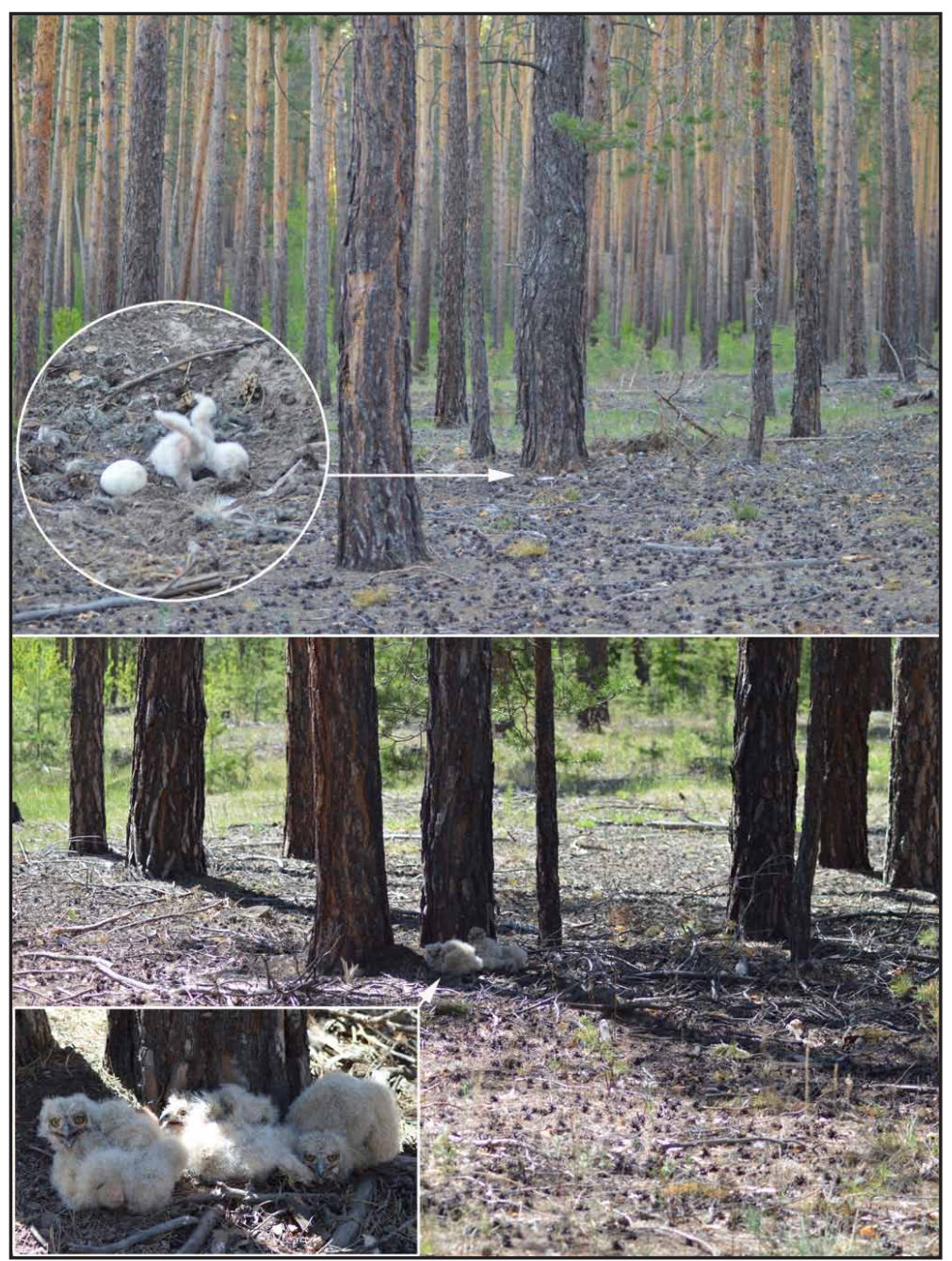

Гнёзда фрилина в борах, пройденных рубками. Фото И. Карякина.

Nests of the Eagle Owls in the pine forests undergone a logging. Photos by I. Karyakin.

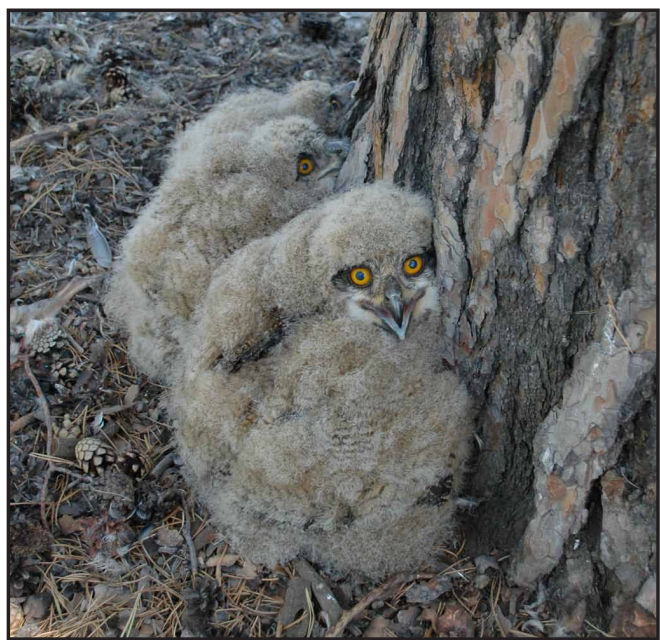

Птенцы фрихина в гнезде под сосной. Фото И. Карякина.

Eagle Owl's nestlings under the pine. Photo by I. Karyakin.

deforestation in the preferable breeding habitats: the outer forest margins and forest edges bordered with lakes, swamps and rivers.

The existing situation is a result of flourish corruption affected nature protection government authorities.

Deforestation lowers breeding success of the wood-breeding population of Eagle Owl and, in part, increases mortality rate of the offspring. Together with the other treats such as poaching and electrocutions it results in reduced number of prospective breeders - the immature non-breeding individuals, and finally mortality rate begins to prevail over birth rate. So the population number reduces.

In the present situation population dynamic projections are pessimistic. As long as there are high quality forest resources in the woods of Altai Kray the situation will hardly become any better. We have to be prepared for the worse - soon Eagle Owl would cross the dangerous line, which is already crossed by such species as Saker Falcon (Falco cherrug) and Golden Eagle (Aquila chrysaetos).

\section{Asknowledgements}

This work was supported by the Russian brunch of the Global Greengrants Fund, Rufford Foundation, and The Senior Management of Nature Resources and Ecology of Altai Kray "Altaipriroda”. We extend grateful thanks to Elvira Nikolenko, Alexey Vagin and Dmitriy Shtol who helped us to search for the Eagle Owl's nests in 2013-2014 in the woods of Altai Region. 


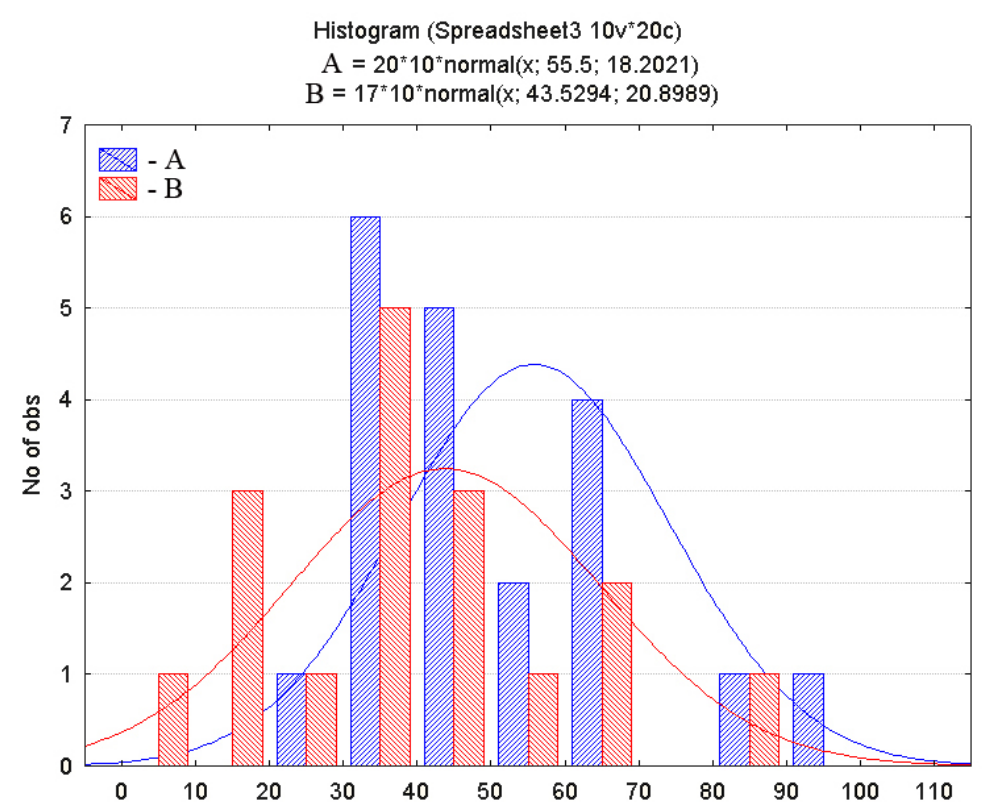

The diameter of the tree trunk at the foot / Диаметр ствола дерева в основании (centimeters / сантиметры)

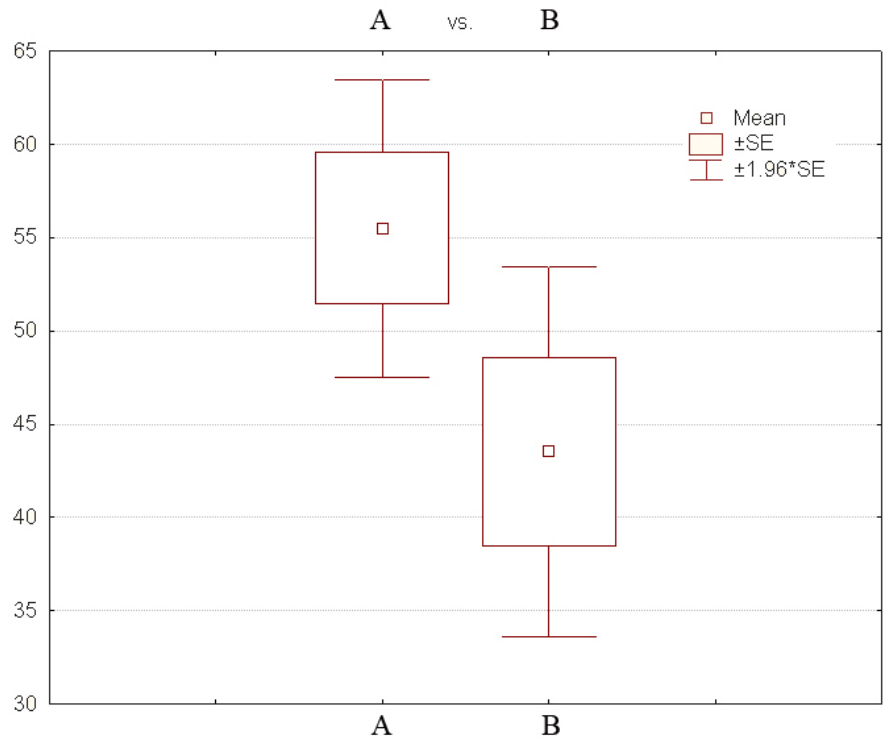

Рис. б. Разница в диаметре гнездовых деревьев, используемых филинами $о$ о 2009 г. - А и в 2014 г. - В.

Fig. 6. The differences in the diameter of pine trees used by Eagle Owls A) before 2009 and B) in 2014. диаметр основания стволов деревьев, под которыми гнездились фрилины, варьировал от 30 Ао 100 см, составляя в среднем ( $n=20)$ 55,5 $\pm 18,2$ см. В настояшее же время диаметр основания стволов деревьев, в подножии которых гнездятся фрилины, составляет в среднем $(n=17) 43,53 \pm 20,9$ см, варьируя от 10 Ао 90 см (рис. 6).

\section{Успех размножения}

Рубки, ведушиеся в борах, в гнездовой период фрилина (с марта по июль) также негативно сказываются на успехе размножения срилина. Из 32-х занятых гнезАовых участков филина, посешавшихся в 2014 г., Аишь на 13 (40,6 \%) было отмечено успешное размножение. Из 19 безуспешных гнездовых участков на 17 рубки велись либо в непосредственной близости от гнёзА, Аибо в ходе рубок были унич-

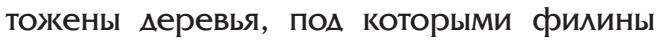
начинами размножение. Можно констатировать тот факт, что более половины пар фрилинов перестали успешно размножаться по причине рубок за посленние 11 мет, так как по данным 2003 г. успешное размножение регистрировалось на $65 \%$ участков $(n=54)$ (Карякин и Ар., 2005), но уже в 2012 г. успех размножения (Аоля успешных участков от числа занятых) составил 41,7 \% (Важов, Рыбальченко, 2013).

Количество птенцов в выводках срилина в 2003-2005 гг. мия всей территории Алтайского края составляло 1-3, в среднем ( $n=23) \quad 1,87 \pm 0,69$ птенцов на успешное гнездо (Карякин и Ар., 2005), в 2012 г. в ленточных борах найдено Ава выводка по три птенца, Ава - по Ава и один - из одного птенца, что составило в среднем $(n=5)$ $2,20 \pm 0,84$ птенца на успешное гнездо (Важов, Рыбальченко, 2013). В 2014 г. выводки филина состояли из 2-4 птенцов, в среднем 3,15 $\pm 0,55$ птенцов на успешное гнездо (рис. 7). ОАнако 2014 г. отличался

стволами сосен, тогАа как в мелкоствольном лесу они хорошо заметны. Соответственно, не находя крупных деревьев, фрилин вынужден гнездится в менее комфортных и менее зашишённых условиях, устраивая гнёзда под мелкими деревьями, что определённо Аолжно негативно сказываться на успехе его размножения. $\triangle$ анных мия анамиза зависимости успеха размножения срилина и размера гнездовых деревьев у нас пока недостаточно, но то, что фрилин в последние годы вынужАен мля гнездования выбирать подножия более мелких деревьев, чем раньше - это фракт $(t$-value $=1,86, d f=35, p=0,07) . \Delta$ o 2009 г.

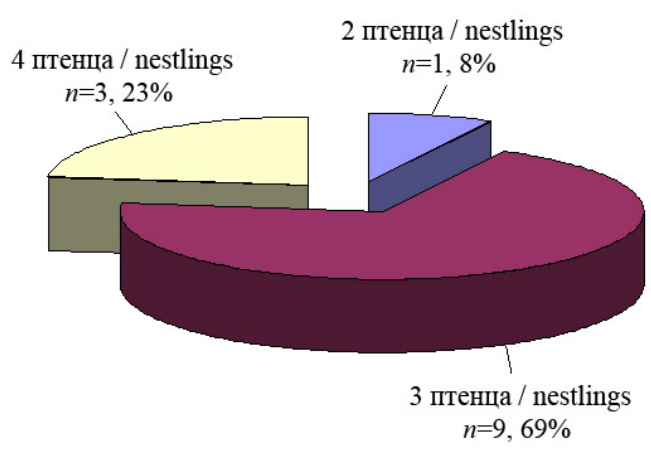

Рис. 7. Размер выводков фииина.

Fig. 7. Brood sizes of the Eagle Owl. 


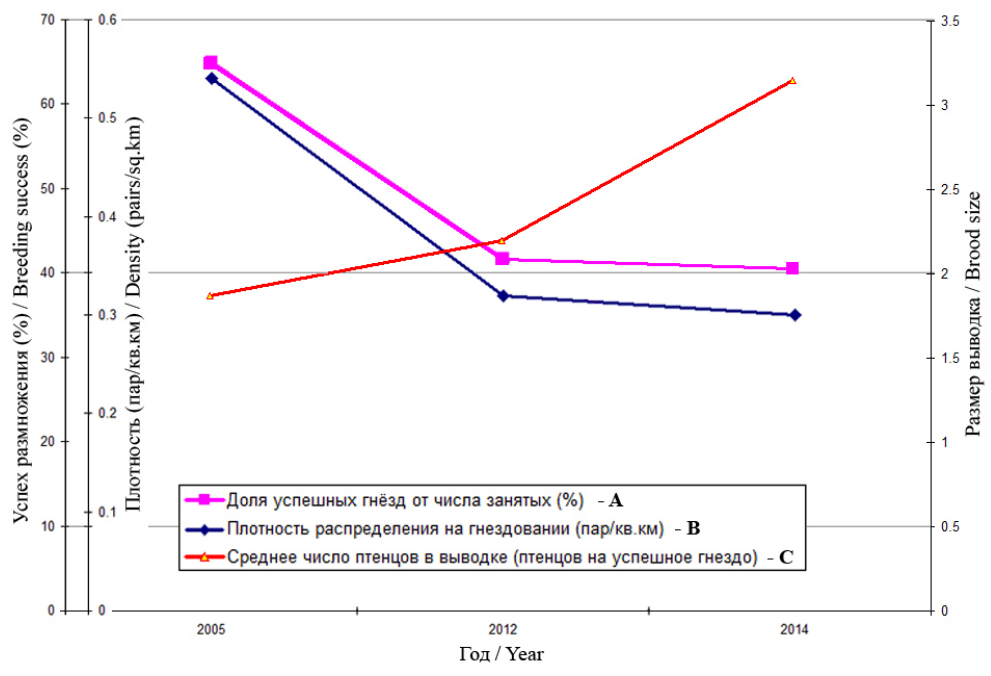

значительным фенологическим сАвигом большая часть фрилинов размножалась на 2-3 нелели позже нормальных сроков и при проверке в большинстве гнёзд нахоАились птенцы в первом пуховом наряле, а не в мезоптиле. Т. е. при проверке не был учтён естественный отход птенцов, что мало более высокие показатели размножения. Но, тем не менее, тенденция увеличения числа птенцов в выводке имеется, и происходит она на фоне падения обшего успеха размножения и сокрашения численности вида (рис. 8). Возможно это популяционный ответ на сокрашение численности под прессом рубок.

\section{Питание}

Анализ останков пиши в гнёздах показывает, что взрослые птицы выкармиивают мелких птенцов преимушественно грызунами - в первую очередь водяными полёвками (Arvicola terrestris), серы-

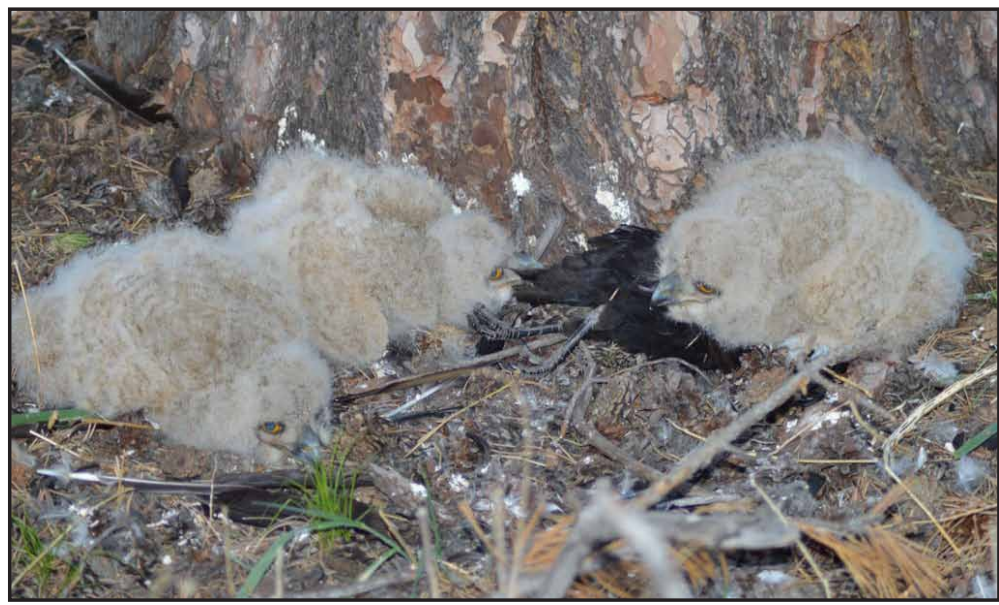

Целая тушка вороны (Corvus cornix) в гнезде филина. Фото И. Карякина.

A carcass of a Hooded Crow (Corvus cornix) in the nest of the Eagle Owl. Photo by I. Karyakin.
Рис. 8. Показатели размножения фимина.

Fig. 8. Breeding features of the Eagle Owl.

A - Percent of successfully breeding pairs out of the total number of breeding pairs (\%);

B - Breeding population density (pairs per $\mathrm{km}^{2}$ ); C Average number of nestlings per nests (nests without nestlings are not counted).

ми и лесными полёвками (Microtus sp., Clethrionomys sp.), хомяками (Cricetus cricetus) и серыми крысами (Rattus norvegicus). По мере взросления птенцов добыча становится крупнее и в ней начинают преоблалать врановые (Corvidae), в основном вороны (Corvus cornix), а также чайки (Larus sp.), утки (Anatidae), поганки (Podicipedidae), мысухи (Fulica atra), хищные птицы, преимушественно коршун (Milvus migrans), канюк (Buteo buteo) и пустельга (Falco tinnunculus), реже зайцы (Lepus europaeus) и лисята (Vulpes vulpes).

\section{Негативные факторы}

Основной угрозой мия филина в Алтайских борах является изменение местообитаний в ходе рубок леса и пожаров, и рубки явно доминируют. Как показано выше, из-за рубок происходит сокрашение гнездопригодных мля фрилина биотопов и большая часть фрилинов не имеет возможности успешно выводить потомство. Низкий успех размножения ведёт к тому, что смертность начинает превамировать нац рожАаемостью, что и ведёт к сокрашению популяции.

В целом мля территории Алтайского края факторы гибели птиц однотипны это гибель на АЭП, браконьерство, уничтожение выводков или плохо летаюших птенцов, гибель на автотрассах.

Известно о четырёх фактах гибели филина на АЭП 6-10 кВ - один выявлен в предгорьях (Карякин и Ар., 2009) и три - в равнинной части Обского левобережья. В оАном случае молодой филин погиб на АЭП в период разлёта выводков и был обнаружен на окраине с. Гилёв Аог Романовского района 21 сентября 2012 г. (Карякин, Николенко, 2013). В Авух мругих случаях обнаружены останки взрослых птиц в гнездовой период на гнездовых участках в Михайловском и Мамонтовском районах - обе птицы погибли на опорах АЭП, идуших вАоль бора, на расстоянии 100-600 м от своих гнёзА.

Протяжённость птицеопасных (^инии 6-10 кВ с оголённым проводом 


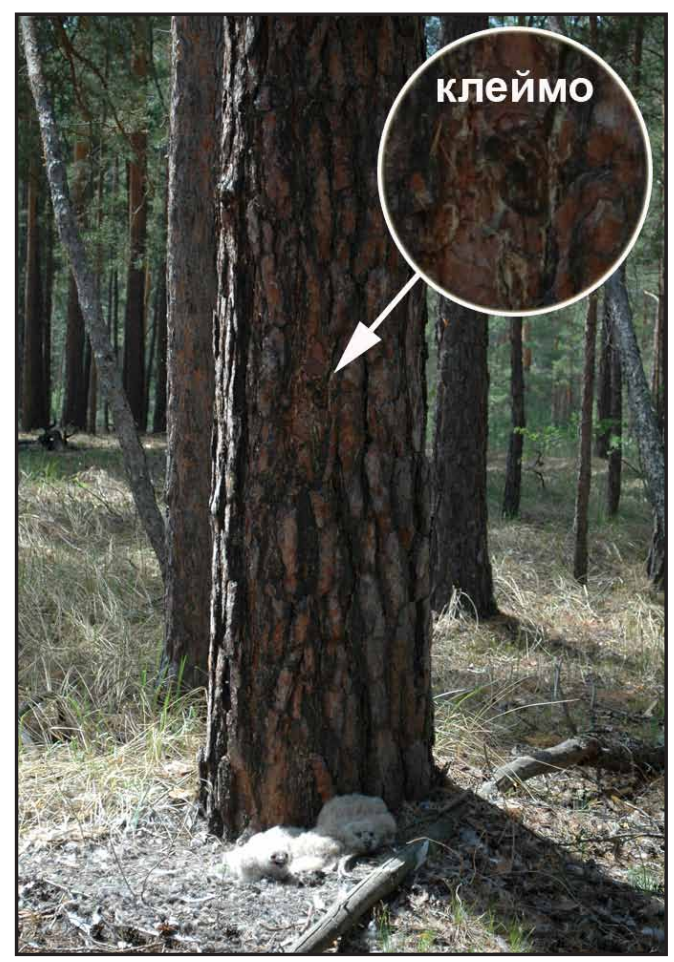

Гнездо фрилина, отведённое под рубку. Фото И. Карякина.

A nest of the Eagle Owl in the wood allotted for logging. Photo by I. Karyakin.

на бетонных опорах с метамлическими траверсами, оснашёнными штыревыми изоляторами) в равнинной части левобережья Оби около 1,2 тыс. км. Учитывая минимальные показатели частоты гибели филина на птицеопасных АЭП в Алтайском крае (от 0,07 ^о 0,23ос./10 км линий: Карякин и Ар., 2009), можно ожидать общий уровень смертности фиАинов на АЭП от 8 Ао 28 особей в год. Это соответствует $3,5-11,5 \%$ от совре-

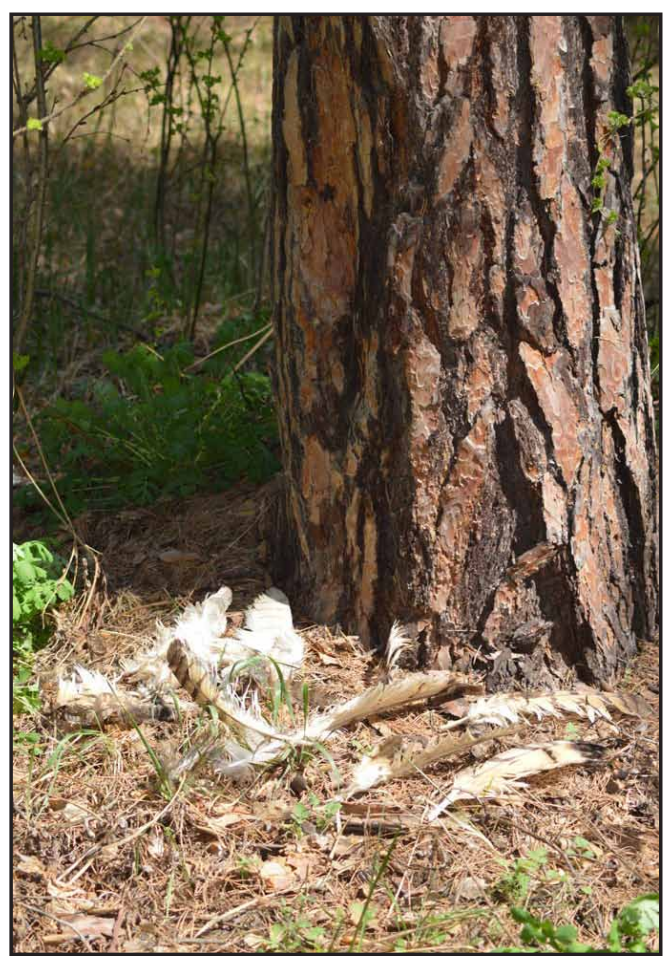

Останки молодого фииина, убитого и съеденного четвероногим хищником. Фото И. Карякина.

Carcass of the young Eagle Owl killed and eaten by the mammalian predator. Photo by I. Karyakin.

менной оценки численности вида. ОАнако, это лишь приблизительная оценка, так как в связи с редкостью филина для более точной оценки требуются более масштабные исследования, чем провеАённые в 2009 г.

Случаи браконьерства становятся стоянием общественности ешё более редко, чем гибель птиц на АЭП. Аоподиинно установлен отстрел фрилинов кишь на трёх участках в борах, причём об этом
Фимин, погибший на

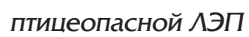
близ с. Ракиты МихайАовского р-на. Труп найден 06.05.2014. Фото И. Карякина.

Eagle Owl killed by electrocution on birdhazardous power line near Rakita village in Mikhaylovskiy district The dead bird was found on 06.05.2014. Photos by I. Karyakin.

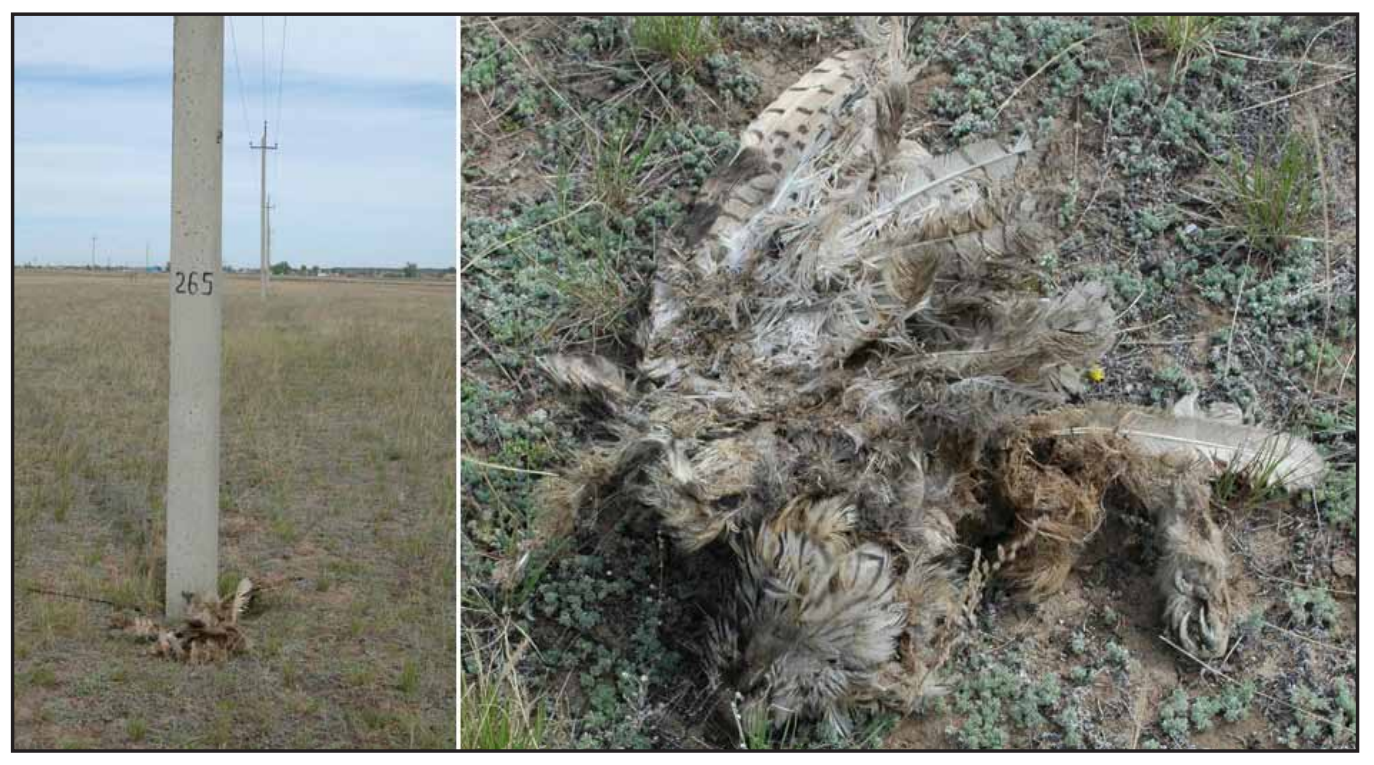


сообшили местные жители со ссылкой на охотников из своих населённых пунктов. В 2014 г. взрослый филин с травмой крыла

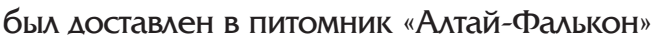
из Егорьевского района также с известного гнездового участка на оз. Кочнёво, где гнездо было отведено в рубку, а позже разорено (вероятно, и взрослых птиц здесь пытались отстрелять). ПреАполагаемый ушерб популяции филина от браконьерства составляет не менее 5-10 \% птиц в год, но в реацьности он может оказаться сушественно выше.

В ходе мониторинга удаётся получать больше инсормации о разорённых гнёзАах и убитых слётках филинов. Как прави^о, это происходит во время рубок - птенцы кибо погибают от переохлажления, мибо уничтожаются собаками, часто присутствуюшими на делянках вместе с людьми, либо изымаются лесорубами с целью Аальнейшей продажи живыми или в виде чучел. Ежегодно удаётся регистрировать несколько таких случаев, в которых фракт

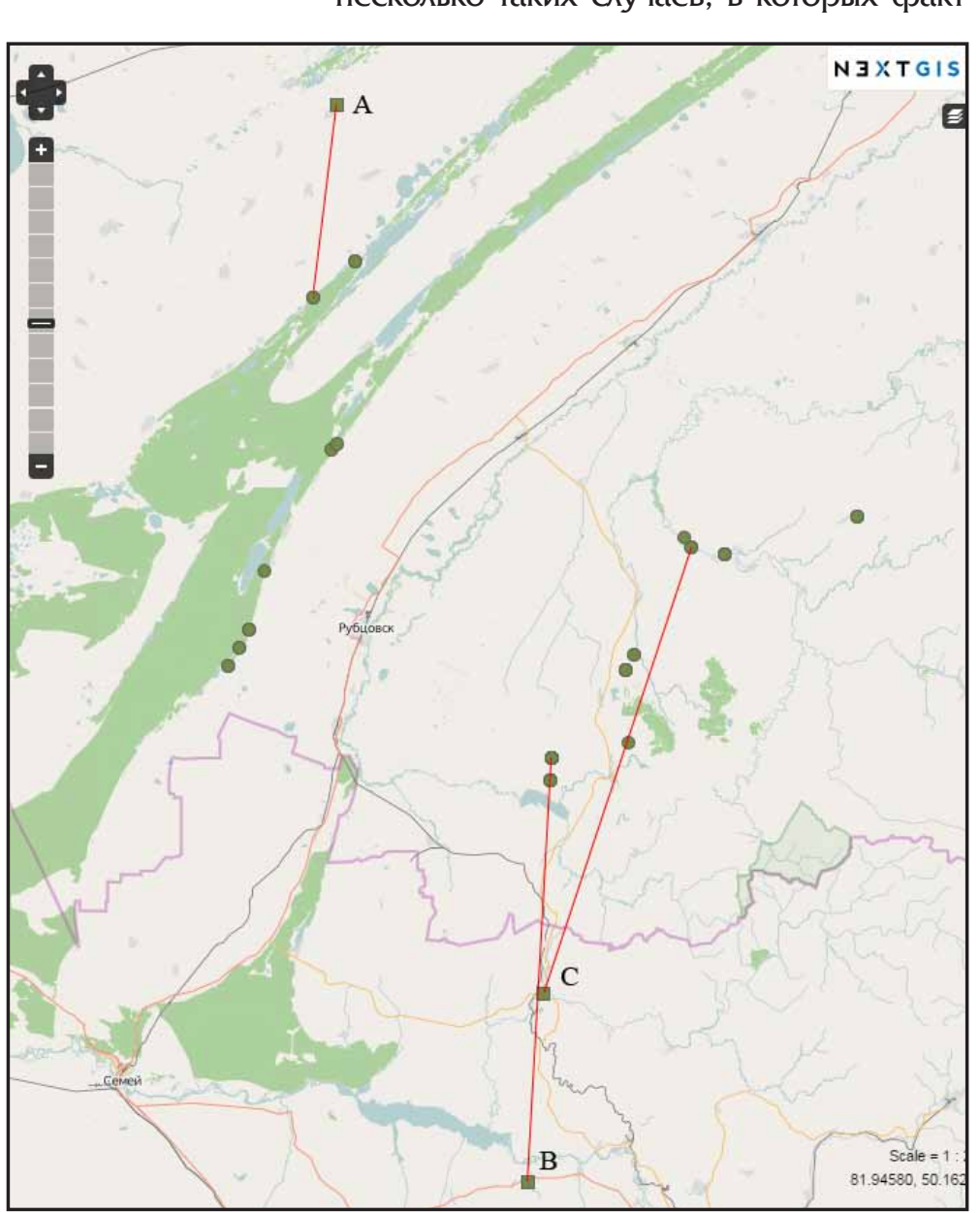

13 http://demo.nextgis.ru/birdreport/report/918

14 http://demo.nextgis.ru/birdreport/report/919

15 http://demo.nextgis.ru/birdreport/report/1257

16 http://demo.nextgis.ru/birdreport/report/1526

17 http://demo.nextgis.ru/birdreport/report/3026

18 http://demo.nextgis.ru/birdreport/report/3027 уничтожения птенцов Аюдьми доказан. В целом же все эти случаи ложатся в обшую массу безуспешных гнёзд наряду с естественными причинами (гибель из-за погодных условий, неАокорма, уничтожения АИкими хишниками и кабанами). Аоля безуспешных гнёзА от числа занятых в 2014 г. составила 59,4\% $(n=32)$.

На автотрассах гибель филина минимаиьна. Известно мишь два случая нахождения сбитых птиц на обочинах асфаиьтированных Аорог, идуших вАоль опушек боров - в Михайловском и Завьяловском районах. В зону риска попадает кишь 12 боровой популяции филина, поэтому ушерб от этого фактора не может быть высоким.

Наибольшей угрозе от всей совокупности факторов, начиная от разорения гнёзА,

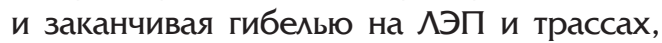
подвержены молодые птицы, которые с сентября начинают широкие перемешения и уходят со своих участков на Аесятки, а то и сотни километров. Визуальные наблюдения показывают, что осенью происходит концентрация молодых птиц вокруг ферм близ населённых пунктов, гле они активно охотятся на доступную концентрируюшуюся там добычу (крысы, врановые, коршуны) и, как следствие, становятся более уязвимыми, нежели в борах.

Возвраты колец (рис. 9) лишь подтвержАают широкий постгнездовой разлёт молодых и гибель на окраинах населённых пунктов (Важов и Ар., 2014):

А - птенец филина, окольцованный автором 25 июля 2012 г. близ с. Селиверстово Волчихинского района Алтайского края ${ }^{13}$ обнаружен погибшим на АЭП на окраине с. Гимёв Лог Романовского района 21 сентября 2012 г. Александром Генераловым ${ }^{14}$ : Аистанция 52 км, азимут 7 градусов, продолжительность жизни 59 Аней.

В - птенец филина, окольцованный Сергеем Важовым в Змеиногоском районе Алтайского края 30 мая 2012 г. ${ }^{15}$ обнаружен погибшим 6 января 2013 г. в зернохранилище пос. Гагарино Уланского района ВКО (Казахстан), о чём сообшил Шербаков Б.В. через Берёзовикова Н.Н. в Казахстанский центр кольцевания ${ }^{16}$ : Аистанция 118 км, азимут 183 градуса, продолжительность жизни 222 Аня.

С - птенец филина, окольцованный Сергеем Важовым в Чарышской степи Алтайского края 28 мая 2014 г. ${ }^{17}$ обнаружен погибшим 16 декабря 2014 г. в кустах у реки в г. Шемонаиха (Казахстан) Алексеем Журавлёвым ${ }^{18}$ : Аистанция 129 


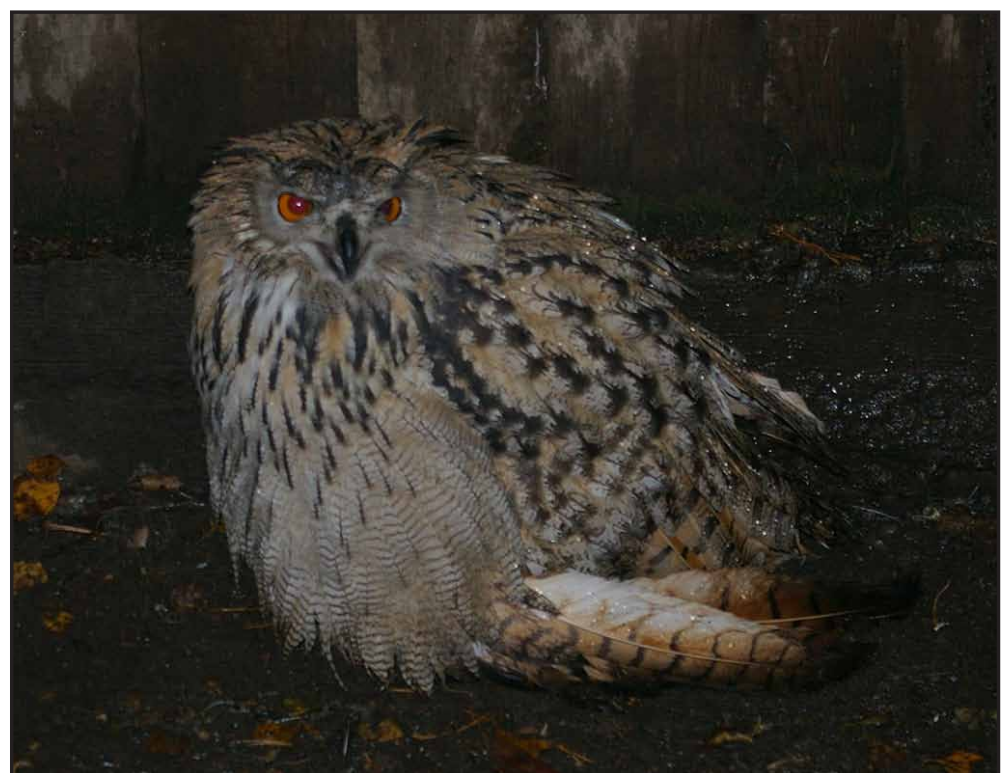

Травмированный филин, Аоставленный в питомник "Аитай-Фалькон". Фото И. Карякина.

Wounded Eagle Owl in the Falcon's sanctuary “Altai-Falcon”. Photo by I. Karyakin.

км, азимут 198,6 градусов, продолжительность жизни 203 Аня.

\section{Закиючение}

Филин - является характерным гнездяшимся видом аитайских боров, но в последнее время его боровая популяция потеряла фактически половину особей, участвуюших в размножении. Причина рубки леса в местах обитания этого вида на внешних опушках боров и по берегам болот, озёр и рек внутри бора.

Сложившаяся ситуация - это результат коррупции, парализовавшей природоохранные органы, прекратившие выявлять и устранять нарушения законодательства, постоянно происходяшие при эксплуа-

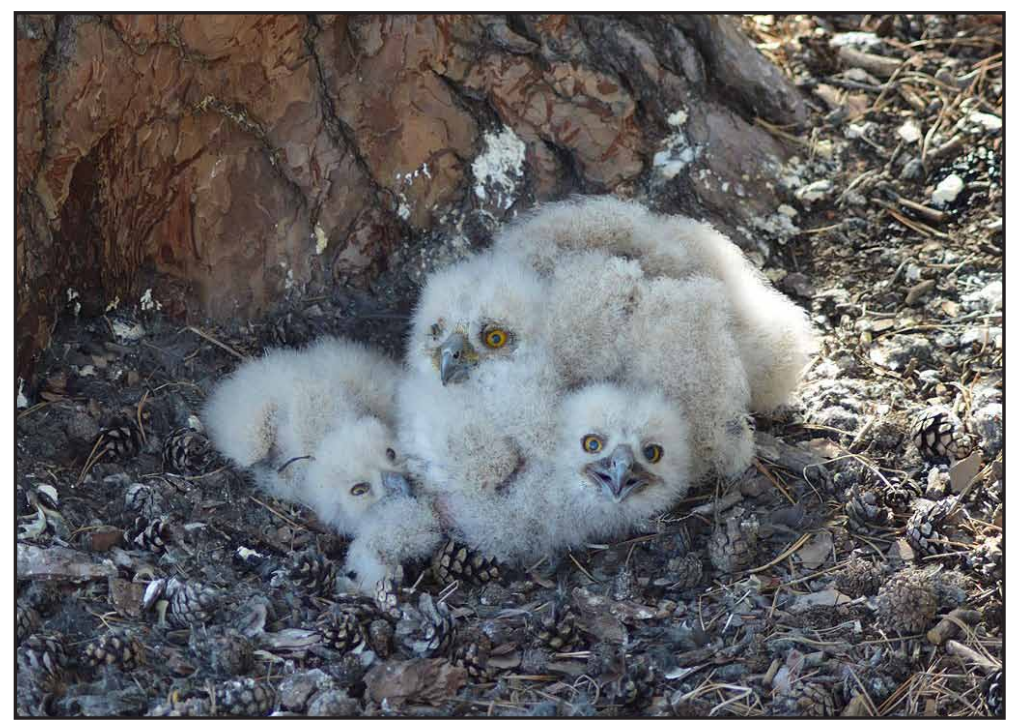

тации лесов, в том числе и на особо-охраняемых природных территориях. Сообшения обшественности о нарушениях закона лесопользователями госоргань игнорируют и скрывают. Аишь отдельные эпизоды активным обшественным Аеятелям удаётся Аовести Ао суда. Арендаторы, в первую очередь холАинг "Алтайлес", чувствуя свою безнаказанность, без особого стеснения уничтожают места обитания редких вилов, в том числе и внесённые в государственный каластр, ведушийся КГБУ "Алтайприрода", и расположенные на регионаиьных особо охраняемых природных территориях.

Рубки подрывают успех размножения боровой популяции филина и, отчасти, непосредственно увеличивают гибель потомства. В результате, на фоне Аругих негативных факторов, таких как гибель на ^ЭП и браконьерство, запас свободных особей сокрашается и смертность начинает превышать рождаемость. В результате численность популяции сокрашается.

В сложившейся ситуации прогнозы Аинамики численности боровой попумяции филина в Алтайском крае более чем пессимистичны. Пока в борах Алтайского края сохраняется лесной ресурс, который возможно осваивать, врял ки ситуация измениться в лучшую сторону. Поэтому необходимо готовиться к худшим прогнозам и ожидать приближения филина к опасной черте, которую уже перешагнули бамобан (Falco cherrug) и беркут (Aquila chrysaetos).

\section{Благодарности}

Автор благодарит Российский Совет Global Greengrants Fund, ФонА Руффорда и КГБУ "Алтайприрода" за финансовую поцдержку экспедиций, а также участников полевых работ, помогавших искать гнёзаа фрилина в 2013-2014 гг. в ленточных борах Алтайского края, особенно Эльвиру Николенко, Алексея Вагина и Амитрия Штоля.

\section{Митература}

Важов С.В. Соколообразные и совообразные российской части предгорий Аитая: экология и распространение. Саарбрюккен, 2012. 196 с.

Птенцы филина в гнезде в бору. Фото И. Карякина. Brood of the Eagle Owl in the nests in pine forest. Photo by I. Karyakin. 
Важов С.В. Филин (Bubo bubo). - Пернатые хишники Мира (Веб-ГИС "Фаунистика"). 2014a. URL: http://raptors.wildlifemonitoring.ru Аата обрашения: 20.10.2014 г.

Важов С.В. Филин (Bubo bubo). - Красная книга Алтайского края (Веб-ГИС «Фаунистика"). 2014b. URL: http://altayredbook. wildlifemonitoring.ru $\triangle$ ата обрашения: 20.10.2014 г.

Важов С., Генералов А., Журавлёв А., Карякин И., Шербаков Б. База Аанных кольцевания птиц. - Российская сеть изучения и охраны пернатых хишников. 2014. URL: http://rrrcn.ru/ ru/ringing/bd Аата обрашения: 20.10.2014 г.

Важов С.В., Рыбаиьченко А.В. Результаты мониторинга некоторых гнездовых участков филина в Алтайском крае в 2012 г., Россия. Пернатые хишники и их охрана. 2013. № 26. С. 109-115.

Воронецкий В.И. Фихин Bubo bubo. - Красная книга Российской Федерации (животные). М.: АСТ, Астрель, 2001. С. 539-540.

Карякин И.В. Распространение и численность филина в Алтае-Саянском регионе, Россия. - Пернатые хищники и их охрана, 2007. № 10. С. 17-36.

Карякин И.В., Николенко Э.Г. О вероятной полигинии у филина, Россия. - Пернатые хищники и их охрана. 2013. № 26. С. 134-135.

Карякин И.В., Николенко Э.Г., Важов С.В., Бекмансуров Р.Х. Гибель пернатых хишников на АЭП на Алтае: результаты исследований 2009 года, Россия. - Пернатые хишники и их охрана. 2009. № 16. С. 45-64.
Карякин И.В., Смелянский И.Э., Бакка С.В., Грабовский М.А., Рыбенко А.В., Егорова А.В. Крупные пернатые хишники Алтайского края. - Пернатые хишники и их охрана, 2005. № 3. C. $28-51$.

Петров В.Ю. Филин - Bubo bubo Linnaeus, 1758. - Красная книга А^тайского края. Редкие и находяшиеся под угрозой исчезновения виды животных. Том 2. Барнаул, 2006. С. $138-140$.

Смелянский И.Э., Карякин И.В., Егорова А.В., Гончарова О., Томиленко А.А. О состоянии некоторых нужАаюшихся в охране видов крупных пернатых хишников в степных предгорьях российского Западного Алтая (Алтайский край). Горные экосистемы Южной Сибири: изучение, охрана, рационаяьное природопользование: Тр. заповедника "Тигирекский". Вып. 1, 2005. С. 345-347.

Смелянский И.Э., Томиленко А.А. Пернатые хишники степных предгорий Русского Алтая: находки 2005 года. - Пернатые хишники и их охрана, 2005. № 3. С. 52-53.

Совообразные. - Российская сеть изучения и охраны пернатых хишников, 2014. URL: http://rrrcn.ru/ru/raptors/owls Аата обрашения: 20.10.2014 г.

Филин (Bubo bubo). - Российская сеть изучения и охраны пернатых хишников, 2014. URL: http://rrrcn.ru/ru/keyspecies/b_bubo Аата обрашения: 20.10.2014 г.

Global Forest Watch. Interactive Map: Forest Change. 2014. URL: http://bit.ly/1LCjmPD. Аата обрашения: 20.10.2014 г.

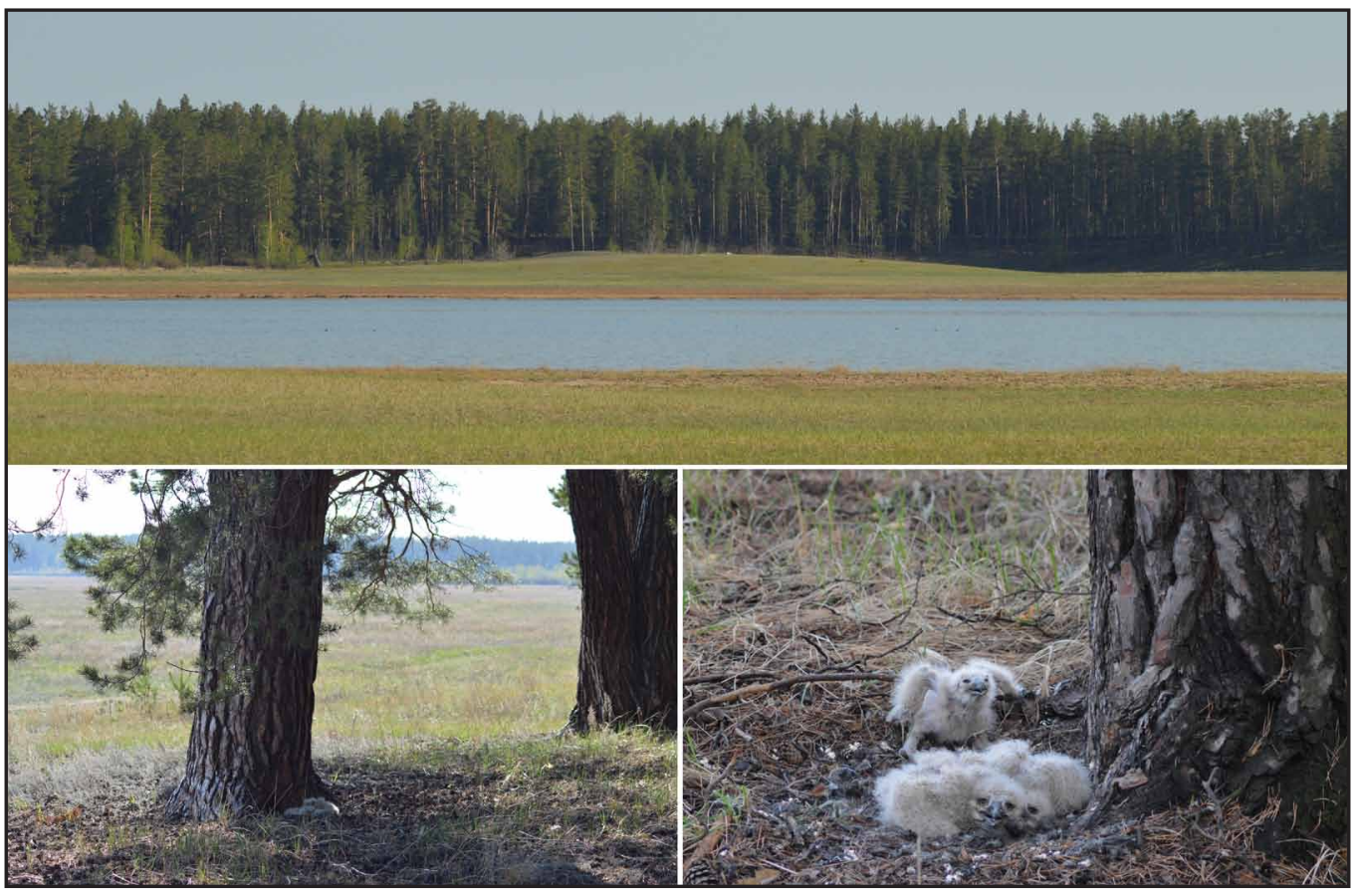

Типичный гнезАовой биотоп фимина (вверху) и киассическое гнездо фримина с птенцами под сосной на опушке бора (внизу). Фото И. Карякина.

The typical breeding habitat of the Eagle Owl (upper) and the typical nest with nestlings under a pine tree on the edge of the pine forest (bottom). Photos by I. Karyakin. 